\title{
Synthesis of a Unique Psammaplysin F Library and Functional Evaluation in Prostate Cancer Cells by Multiparametric Quantitative Single Cell Imaging
}

Rohitesh Kumar, ${ }^{\dagger}$ Charles L. Bidgood, ${ }^{\ddagger}$ Claire Levrier, ${ }^{\ddagger}$ Jennifer H. Gunter, ${ }^{\ddagger}$ Colleen C. Nelson,${ }^{\ddagger}$ Martin C. Sadowski,${ }^{\ddagger}$ and Rohan A. Davis $* \dagger$

${ }^{+}$Griffith Institute for Drug Discovery, School of Environment and Science, Griffith University, Brisbane, QLD 4111, Australia.

${ }^{\ddagger}$ Australian Prostate Cancer Research Centre-Queensland, Institute of Health and Biomedical Innovation, Queensland University of Technology, Princess Alexandra Hospital, Translational Research Institute, Brisbane, QLD 4102, Australia.

\begin{abstract}
The spirooxepinisoxazoline alkaloid, psammaplysin F (1), was selected as a scaffold for the generation of a unique screening library for both drug discovery and chemical biology research. Large-scale extraction and isolation chemistry was performed on a marine sponge (Hyattella sp.) collected from the Great Barrier Reef in order to acquire $>200 \mathrm{mg}$ of the desired bromotyrosine-derived alkaloidal scaffold. Parallel solution-phase semi-synthesis was employed to generate a series of psammaplysin-based urea (2-9) and amide analogs (10-11) in low to moderate yields. The chemical structures of all analogs were characterized using NMR and MS data. The absolute configuration of psammaplysin $\mathrm{F}$ and all semi-synthetic analogs was determined as $6 R, 7 R$ by comparison of ECD data with literature values. All compounds (1-11) were evaluated for their effect on cell cycle distribution and changes to cancer metabolism in LNCaP prostate cancer cells using a multiparametric quantitative single cell imaging approach. These investigations identified that in LNCaP cells psammaplysin F and some urea analogs caused loss of mitochondrial membrane potential, fragmentation of the mitochondrial tubular network, chromosome misalignment and cell cycle arrest in mitosis.
\end{abstract}


With the oceans covering $\sim 70 \%$ of the earth's surface, the marine environment represents a unique source of novel small molecules that have the potential to impact both drug discovery and chemical biology research. ${ }^{1-3}$ While marine biota have only been chemically and pharmacologically investigated for the past six decades, a number of marine-derived compounds are already available as commercial drugs or are in clinical trials. ${ }^{4,5}$ Examples of marine drugs include trabectedin ${ }^{6}$ (Yondelis ${ }^{\mathrm{TM}}$ ), isolated from Ecteinascidia turbinata, which is used for the treatment of advanced soft tissue sarcoma, ${ }^{7}$ and the peptide $\omega$-conotoxin (Ziconitide ${ }^{\mathrm{TM}}$ ) isolated from Conus catus, used for the treatment of chronic and neuropathic pain. ${ }^{5}$ Examples of marinederived drugs include eribulin ${ }^{8}$ (Halaven ${ }^{\mathrm{TM}}$ ), which is a synthetic truncated derivative of halichondrin $\mathrm{B}^{5}$ that was approved by the FDA for the treatment of refractory metastatic breast cancer, ${ }^{9}$ and panobinostat ${ }^{10}$ (Farydak ${ }^{\mathrm{TM}}$ ), derived from the lead compound psammaplin A, which has recently been approved for the treatment of multiple myeloma. ${ }^{11}$

The use of natural products as scaffolds for the generation of novel compound libraries has been well documented ${ }^{12-14}$ and avoids challenges associated with de novo synthesis, which can be both time consuming and expensive. ${ }^{12,15}$ This approach incorporates the chemical diversity found in natural products and results in analogs being synthesized that allows valuable structure-activity relationship (SAR) data to be elucidated for drug discovery and chemical biology purposes. ${ }^{16}$ Taking advantage of Australia's significant biodiversity and the associated chemical diversity, the Davis group undertakes large-scale extraction and isolation chemistry on locally-sourced marine or terrestrial biota in order to obtain sufficient quantities of natural products for subsequent semi-synthesis studies that result in the generation of unique libraries that can be applied to both drug discovery and chemical biology research. ${ }^{17-20}$

Marine sponges have been a significant source of unique chemistry over the decades, with 9231 sponge-derived secondary metabolites currently reported in the literature. ${ }^{21-23}$ This equates to $\sim 26 \%$ of all marine natural products identified to date, ${ }^{22}$ an impressive contribution. Whilst over the past three years the number of new sponge-derived metabolites being reported per annum indicates a clear downward trend, primarily due to marine natural product chemists changing their focus to the study of marine microorganisms, ${ }^{21,23,24}$ sponges still remain an important taxonomic group for the discovery of new and bioactive natural products and certainly still warrant both chemical and biological investigations. For instance, sponges belonging to the order Verongiida, ${ }^{25,26}$ have been a prolific source of bioactive bromotyrosine-derived alkaloids 
with more than 300 compounds currently reported. ${ }^{27}$ This particular structure class is divided into six categories, which includes simple bromotyrosine derivatives, spirocyclohexadienylisoxazolines, spirooxepinisoxazolines, oximes, bastadins, and other bromotyrosine-derived alkaloid structural classes. ${ }^{27,28}$ Bromotyrosine alkaloids possessing the unique spirooxepinisoxazoline moiety are one of the most architecturally interesting and bioactive derivatives. ${ }^{29,30}$ To date, 33 metabolites with this rare and unique moiety (psammaplysins $\mathrm{A}-\mathrm{Y}$ and ceratinamides $\mathrm{A}-\mathrm{B}$ ) have been isolated from various sponges ${ }^{31}$ and have been shown to display a wide range of biological properties including cytotoxicity, ${ }^{31-33}$ antibacterial, ${ }^{34,35}$ antimalarial, ${ }^{36}$ anti-HIV ${ }^{37,38}$ and antifouling ${ }^{38}$ activities.

As part of our continuing research into the generation of natural product-based compound libraries for drug discovery and chemical biology purposes, psammaplysin F (1) was identified as a desirable chemical scaffold for semi-synthesis studies. This compounds high-abundance in the sponge, complex and unique 3D architecture, noteworthy biological activity, ${ }^{39-41}$ and the presence of secondary hydroxy and amine groups, which would serve as chemical handles for structural modifications, made psammaplysin F (1) a suitable and appealing scaffold for semisynthesis. Psammaplysin F had been previously identified by Griffith Institute for Drug Discovery (GRIDD) researchers during an antimalarial biodiscovery project, ${ }^{36}$ hence a sponge source (Hyattella sp.) for this molecule was already known and fortuitously available in abundant supplies from GRIDD's NatureBank biota repository. ${ }^{42}$ The urea functional group and its derivatives are prevalent in many biologically active compounds as exemplified by a number of FDA approved drugs. ${ }^{43}$ Examples include sorafenib (Nexavar ${ }^{\mathrm{TM}}$ ), lenvatinib (Lenvima ${ }^{\mathrm{TM}}$ ), and lisuride (Dopergin ${ }^{\mathrm{TM}}$ ) all of which are urea containing drugs that are used to treat hepatocellular and advanced renal cell carcinoma, thyroid cancer, and Parkinson's disease, respectively. ${ }^{43}$ Due to this functional groups broad application to medicinal chemistry, we decided to explore means by which we could incorporate the urea moiety into our semi-synthetic workflow using a unique and chemically amenable natural product scaffold. Herein we report the large-scale extraction and isolation of psammaplysin $\mathrm{F}$, the semi-synthesis and characterization of a novel alkaloidbased library and the subsequent cancer-related biological evaluation using a multiparametric quantitative single cell imaging approach.

\section{Results and Discussion}


The target scaffold 1 was purified from the Great Barrier Reef sponge Hyattella sp. following large-scale solvent extraction of the freeze-dried and ground sponge material followed by extensive $\mathrm{C}_{18} \mathrm{HPLC}\left(\mathrm{MeOH} / \mathrm{H}_{2} \mathrm{O} / 0.1 \%\right.$ TFA) separation, which resulted in $290 \mathrm{mg}(0.630 \%$ dry wt) of the TFA salt of psammaplysin F (1). ${ }^{36}$ Compound $\mathbf{1}$ was dissolved in anhydrous $\mathrm{CH}_{2} \mathrm{Cl}_{2}$ / pyridine then reacted with a series of commercially available isocyanates for $16 \mathrm{~h}$ at room temperature (Figure 1). Subsequent HPLC purification of the reaction mixture yielded eight semi-synthetic psammaplysin F derivatives (2-9) with yields ranging from 8-59\%. Since the amine functionality of the psammaplysin $\mathrm{F}$ is more nucleophilic than the secondary hydroxy group, all the isocyanates preferentially reacted with the amine resulting in urea analogs however some reactivity at the secondary alcohol $(7-\mathrm{OH})$ was also identified and is exemplified by compound 9.

Furthermore, two amide analogs of psammaplysin $\mathrm{F}$ were also generated by acylation using pivaloyl chloride. This was achieved by adding pivaloyl chloride to a solution of compound 1 in anhydrous pyridine at $0{ }^{\circ} \mathrm{C}$. Following HPLC purification the two pivaloylated analogs (10 and 11) were obtained in low yields (6\%). The structures of all the new analogs $(2-$ 11) were characterized following $1 \mathrm{D}\left({ }^{1} \mathrm{H}\right.$ and $\left.{ }^{13} \mathrm{C}\right)$ and $2 \mathrm{D}$ (COSY, HSQC, HMBC, and ROESY) NMR, UV, $[\alpha]_{D}, E C D$ and MS data analysis. The structural confirmation of one of the urea analogs, compound 7, is briefly described below.

The HRESIMS of 7 exhibited a sodium adduct ion peak at $m / z 944.8935$ corresponding to the molecular formula $\mathrm{C}_{31} \mathrm{H}_{34}{ }^{79} \mathrm{Br}_{4} \mathrm{~N}_{4} \mathrm{NaO}_{9}[\mathrm{M}+\mathrm{Na}]^{+}$of the desired product. Furthermore, all the ${ }^{1} \mathrm{H}$ and ${ }^{13} \mathrm{C}$ chemical shifts in DMSO- $d_{6}$ of the psammaplysin $\mathrm{F}$ substructure of 7 were assigned following comparison with psammaplysin F literature values ${ }^{36,38}$ (see Table $\mathrm{S} 1$ in the Supporting Information for NMR data comparison) and confirmed by analysis of the 2D NMR (COSY, HSQC, HMBC, and ROESY) data. Of note, the presence of the exchangeable proton 7$\mathrm{OH}\left(\delta_{\mathrm{H}} 7.02, \mathrm{~d}, J=7.7 \mathrm{~Hz}\right)$ and the chemical shift of the methine proton $\mathrm{H}-7\left(\delta_{\mathrm{H}} 4.90, \mathrm{~d}, J=7.7\right.$ $\mathrm{Hz}$ ) in 7 confirmed that the isocyanates favoured the formation of urea analogs. HMBC correlations from the $N$-methyl protons $\left(\delta_{\mathrm{H}} 2.94, \mathrm{~s}\right)$ to the urea carbonyl carbon $\left(\delta_{\mathrm{C}} 154.8, \mathrm{C}-22\right)$ and methylene carbon $\left(\delta_{\mathrm{C}} 49.5, \mathrm{C}-20\right)$ further confirmed the formation of the urea bond. All key COSY, HMBC and ROESY correlations for compound 7 as shown below in Figure 2. 
The absolute configuration of psammaplysin A, the $N$-demethyl analog of psammaplysin $\mathrm{F}$, had been conclusively determined by Garson et al. as $6 R, 7 R$ using experimental and calculated electronic circular dichroism (ECD) data and NMR data analysis of MPA esters prepared from the acetamide derivative of psammaplysin $\mathrm{A}^{30}$ The ECD spectrum of psammaplysin $\mathrm{F}$ in $\mathrm{MeOH}$ (Figure 3) exhibited a broad negative Cotton effect (CE) at $274 \mathrm{~nm}$, a positive $\mathrm{CE}$ at $240 \mathrm{~nm}$ and a strong negative $\mathrm{CE}$ at $213 \mathrm{~nm}$, which closely matched the ECD spectrum of psammaplysin A [MeOH, $\lambda_{\max }(\mathrm{nm})(\Delta \varepsilon) 284(-1.07), 240$ (9.97), $235 \mathrm{sh}(9.49), 206$ $(-30.80)] .{ }^{30}$ Based on the near identical ECD spectra of psammaplysins A and F the absolute configuration for alkaloid 1 was also assigned as $6 R, 7 R$. All semi-synthetic psammaplysin $\mathrm{F}$ analogs (2-11) were also assigned absolute configurations of $6 R, 7 R$ due to their derivatisation from 1; ECD data for 2-11 supported these assignments (Figure 3).

Our previous work reported psammaplysin F's inhibitory activity against chemotherapyinduced stress granule formation in multiple cancer cell lines. ${ }^{39}$ The assembly of stress granules has been associated with the onset of the DNA damage response (DDR), ${ }^{44}$ suggesting a potential activity of psammaplysin F (1) in DNA-related processes. For a more comprehensive biological evaluation of psammaplysin F (1) and analogs (2-11) we analyzed several cancer-relevant cellular processes related to stress response and therapy resistance and applied multiparametric quantitative single cell imaging (mqSCI). mqSCI is based on automated fluorescence microscopy of multiple fluorescent reporter probes and automated image analysis of signal intensity and localization to simultaneously interrogate several biological processes and their functional interactions with subcellular precision. mqSCI analysis of cell cycle distribution based on DNA staining of LNCaP prostate cancer cells after treatment with psammaplysin F (1) and analogs (211) at $50 \mu \mathrm{M}$ revealed a strong disruption of mitosis by the parent compound 1, including metaphase chromosome misalignment and DNA fragmentation (Figure 4D) similar to previously described microtubule inhibitors $6 \alpha$-acetoxyanopterine $(6 \mathrm{AA})^{45}$ (for chemical structure see Figure S61, Supporting Information) and vinblastine (VINB) causing cell cycle arrest in mitosis. ${ }^{46,47}$ Like $\mathbf{1}$, analogs $2,4,5,6,8,10$, and 11 visibly caused accumulation of cells in the $\mathrm{G}_{2} / \mathrm{M}$ phase of the cell cycle (Figure $4 \mathrm{~A}-\mathrm{C}$ ). This cell cycle phenotype was also observed in PC3 prostate cancer cells (data not shown). In contrast, analogs 3, 7 and 9 did not affect cell cycle progression and were indistinguishable from vehicle control (DMSO). Notably, analogs 2 and 10 
increased cell death to levels seen after treatment with 6AA and VINB (Figure 4A and C) as indicated by an increase in the number of cells with reduced DNA content ( $\left(\mathrm{sub}_{0} / \mathrm{G}_{1}\right.$ ).

Simultaneously, we measured changes to mitochondrial function and morphology by mqSCI of LNCaP cells stained with tetramethylrhodamine ethyl ester (TMRE) and MitoTracker Green (MTG, Figure 5). While retention of TMRE in active mitochondria is proportional to their membrane potential, MTG is a passive stain for the detection of all mitochondria (active and inactive) ${ }^{48}$ Mitochondrial activity and morphology are directly linked to cell cycle progression. ${ }^{49}$ The mitochondrial network undergoes fragmentation (fission) early in mitosis ${ }^{49}$ and strong membrane depolarization in the later phases of mitosis. ${ }^{50}$ Compounds 1 (Figure 6A), 2, 8, 10, and 11 (Figure 6E) strongly reduced mitochondrial membrane potential (MMP) ${ }^{51}$ to levels seen with the potent protonophore and uncoupler of mitochondrial oxidative phosphorylation, carbonyl cyanide-4-phenylhydrazone (FCCP) (for chemical structure see, Figure S61, Supporting Information). Compounds 3-7 and 9 lacked this inhibitory activity (Figure S75, Supporting Information). In addition to a strong inhibition of mitochondrial activity, psammaplysin F (1) strongly affected mitochondrial morphology and reduced the number of branch-points and endpoints within the tubular structure of individual mitochondria (Figure 6B, C, D), leading to visible fragmentation of the mitochondrial tubular network seen in vehicle control-treated cells (Figure 5). Together, this data implies severe disruption of mitochondrial activity and morphology by psammaplysin F (1) underpinned by increased fission, ultimately suggesting induction of metabolic disturbance. ${ }^{52}$ These changes in mitochondrial morphology are well documented to coincide with altered oxidative capacity and glycolysis regulation to facilitate cell division. ${ }^{49}$ The inhibitory effect on MMP is in contrast to the microtubule inhibitors 6AA and VINB, which increased MMP, strongly suggesting that psammaplysin F has a different mechanism of action (Figure S74, Supporting Information). Also, the stark difference in the relatively low number of $\mathrm{G}_{2} / \mathrm{M}$ arrested cells (Figure $4 \mathrm{~A}$ ) but universal loss of MMP (Figure 6A) at equimolar doses strongly suggest that the mitotic arrest is not causative for the loss in mitochondrial activity. Taken together, mqSCI identified novel biological activities associated with psammaplysin F (1) in prostate cancer cells (disruption of chromosome alignment and mitochondrial activity) and indicated that changes to the amide functionality ( $\mathrm{R}_{1}$ substitutions) of the analogs affected these activities. Other SAR insights were gleaned from the mqSCI studies on the library. For instance, mitochondrial activity data indicated that in the urea series (2-9) if 
the hydrogen associated with 20-NH of compound $\mathbf{1}$ was substituted by bulky groups such as benzyl (3), phenethyl (6), phenyl $(4,7$, and 9) or a cyclic alkane (5), the inhibitory activity was lost (Figure S75, Supporting Information). Interestingly, replacement of the 20-NH hydrogen with simple side chains such as those present in $\mathbf{2}$ and $\mathbf{8}$ retained this particular activity, which could be due to the lipophilicity of the molecules. These findings provide a strong rationale for more detailed mechanistic studies of psammaplysin $\mathrm{F}$ and derivatives as novel mitochondrial poisons.

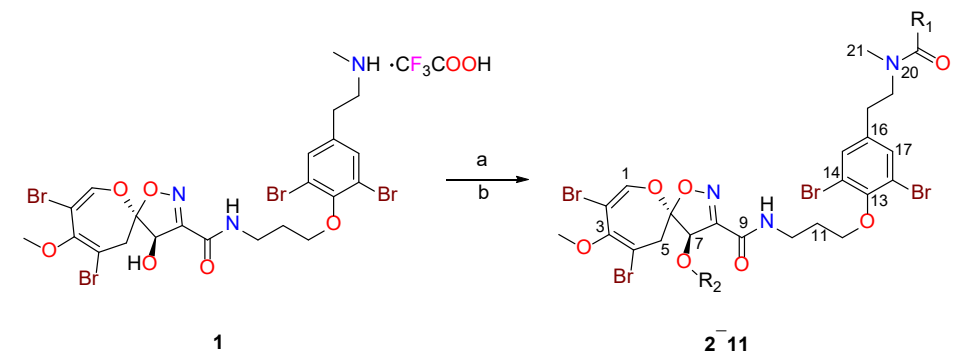

(n)

Figure 1: (a). Generation and chemical structures of urea analogs (2-9): $\mathrm{CH}_{2} \mathrm{Cl}_{2}$, pyridine, isocyanates, rt, 16 h. (b). Generation and chemical structures of amide analogs (10-11): pyridine, pivaloyl chloride, $0^{\circ} \mathrm{C}$ to $\mathrm{rt}, 16 \mathrm{~h}$. 


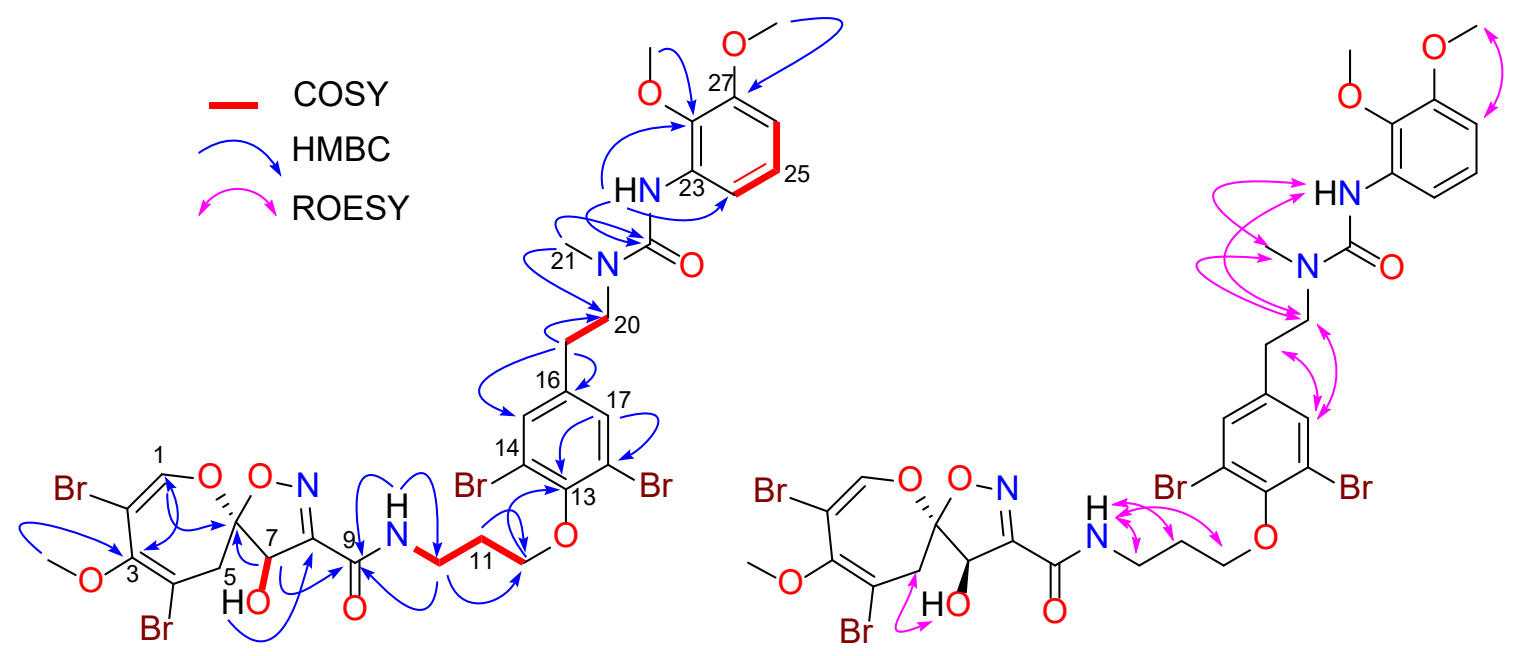

Figure 2. Selected COSY, HMBC, and ROESY correlations for compound 7.

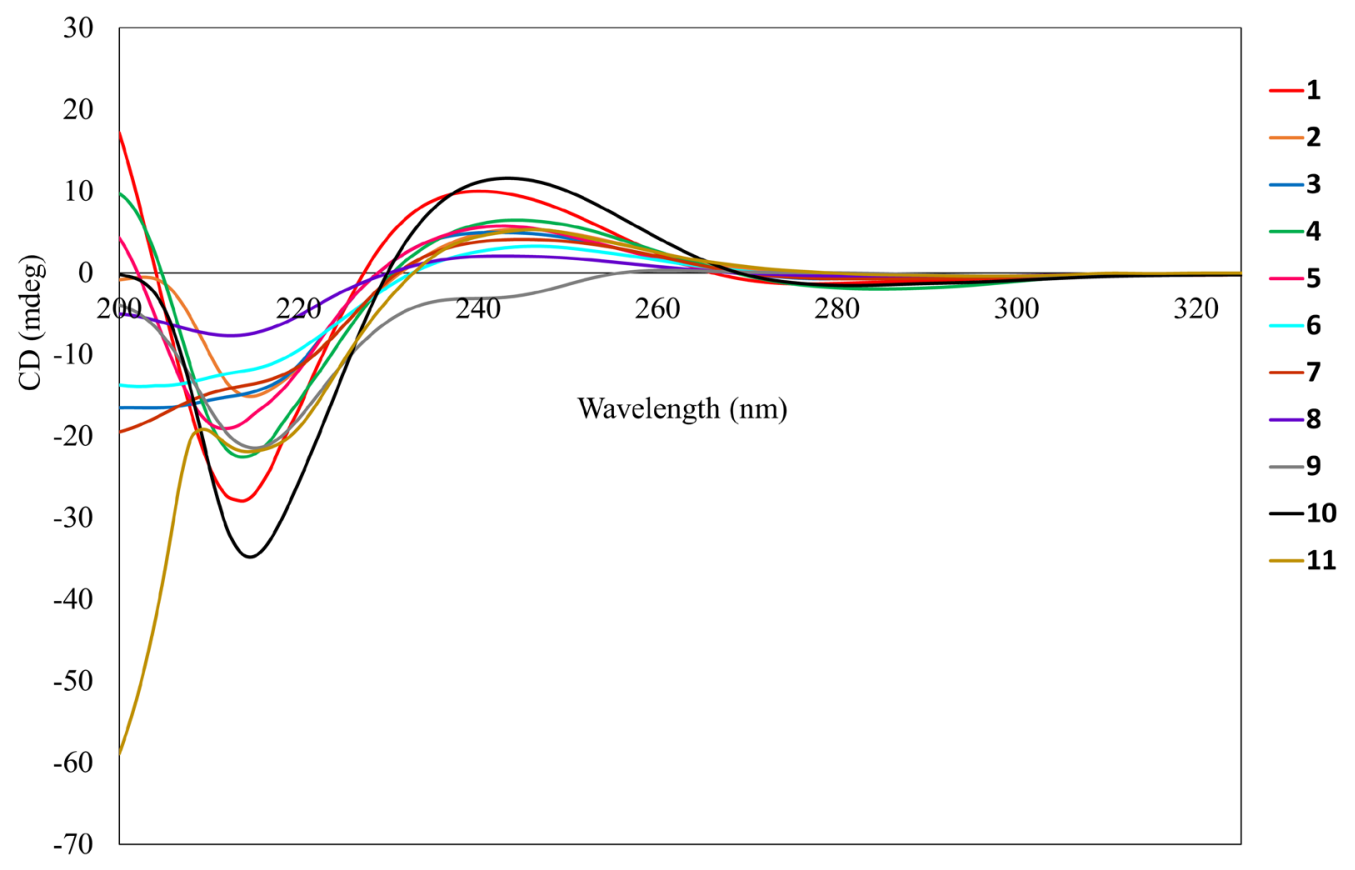

Figure 3: Experimental ECD spectra for compounds 1-11 in $\mathrm{MeOH}$. 

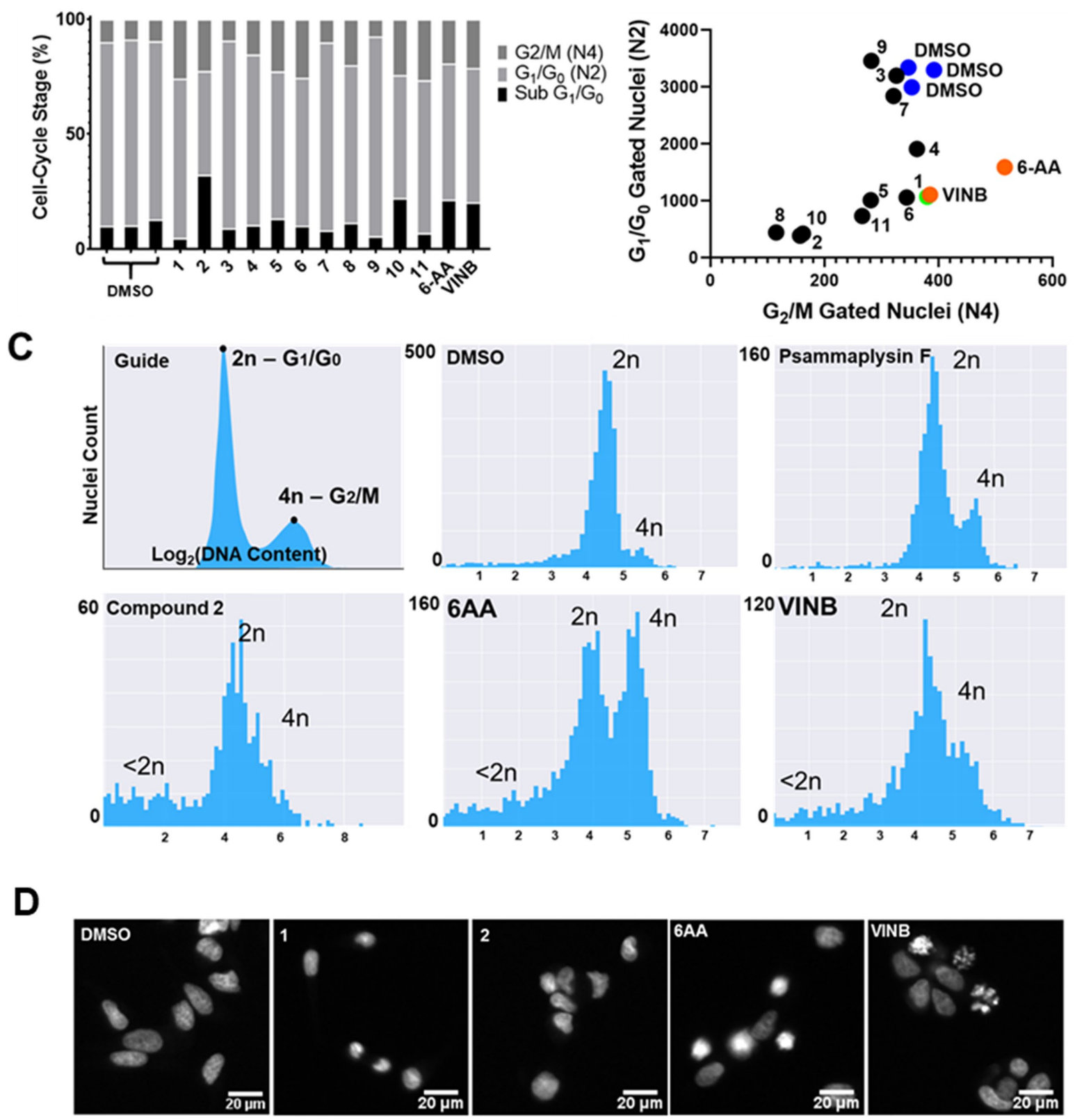

Figure 4: Psammaplysin F (1), synthesized derivatives (2-11) and mitotic inhibitors 6aacetoxyanopterine $(6 \mathrm{AA}, 5 \mathrm{nM})^{45}$ and vinblastine (VINB, $12.5 \mathrm{nM}$ ) impede cell cycle progression of $\mathrm{LNCaP}$ cells compared to DMSO (representative controls are shown for each microscopy plate containing compounds 1-11). (A) Cell cycle distribution of cells in the $\mathrm{G}_{0} / \mathrm{G}_{1}$ (2n DNA) and $\mathrm{G}_{2} / \mathrm{M}$ (4n DNA) phases were measured based on the integrated fluorescent intensity of nuclear DNA staining with Hoechst 33342. (B) Population analysis of compounds 
and positive controls (6AA, VINB) showing number of nuclei gated with $\mathrm{G}_{0} / \mathrm{G}_{1}$ versus $\mathrm{G}_{2} / \mathrm{M}$ cell-cycle status. (C) Total nuclear content histogram generated using integrated fluorescent intensity of Hoechst 33342 staining with visual representation of $2 \mathrm{n}$ and $4 \mathrm{n}$ ploidy status $(\log 2$ transformed). Cell cycle gating was performed using PopulationProfiler ${ }^{53}$ (https://github.com/dimatusz/PopulationProfiler). (D) Representative 40× images of Hoechst 33342 stained LNCaP nuclei respective of treatment. 


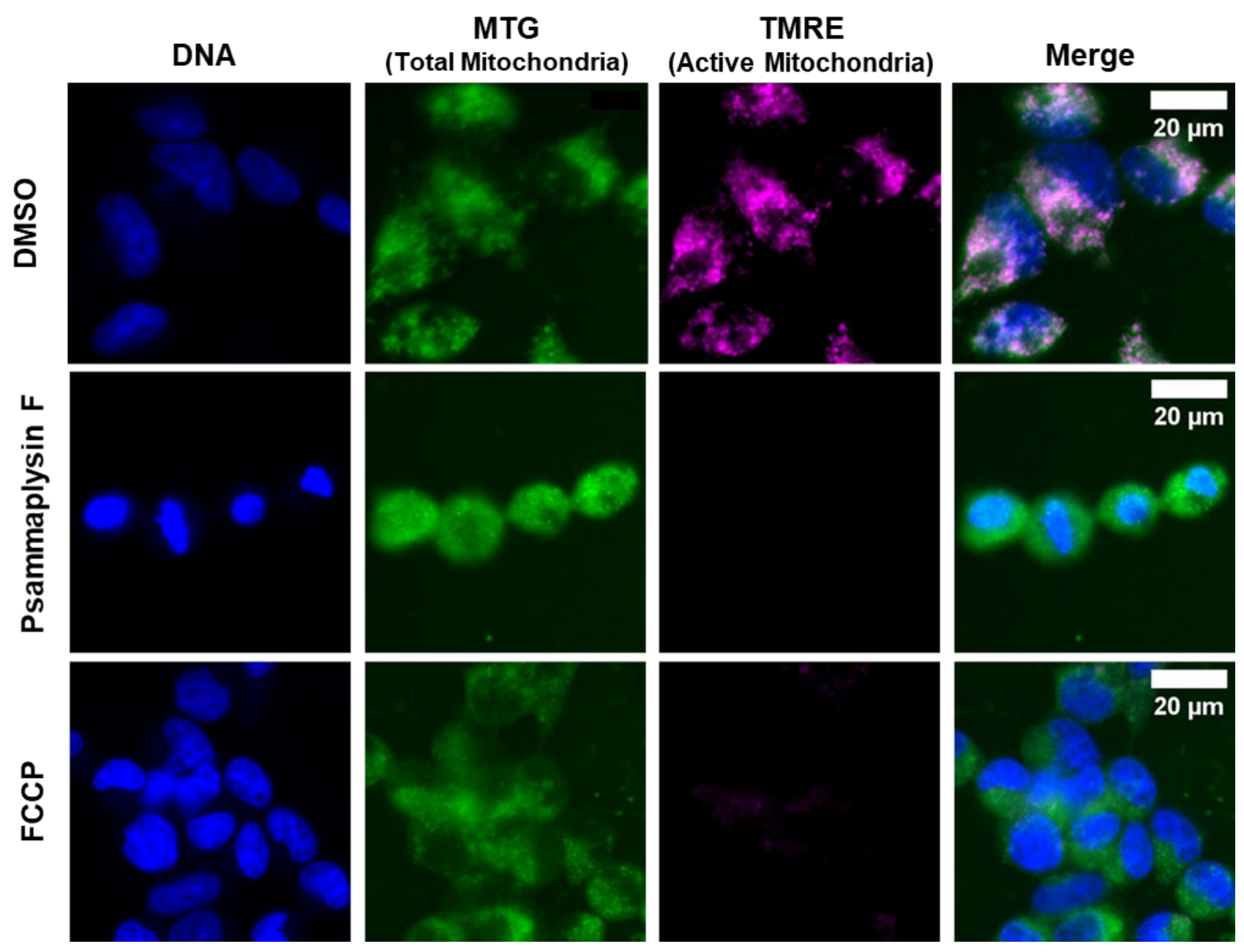

Figure 5: Representative images at 40× magnification of $\mathrm{LNCaP}$ cells treated for $24 \mathrm{~h}$ with psammaplysin F (1) $(50 \mu \mathrm{M})$ and FCCP $(30 \mu \mathrm{M})$ treatment followed by staining with Hoechst 33342 (DNA), MitoTracker Green (MTG, membrane potential-independent stain = total mitochondria) and tetramethylrhodamine ethyl ester (TMRE, membrane potential-dependent stain $=$ active mitochondria). The inhibitory and morphology-changing effects of psammaplysin F (1) and FCCP are highlighted by a strong reduction in TMRE staining and different mitochondrial organization when compared to vehicle control (DMSO). 


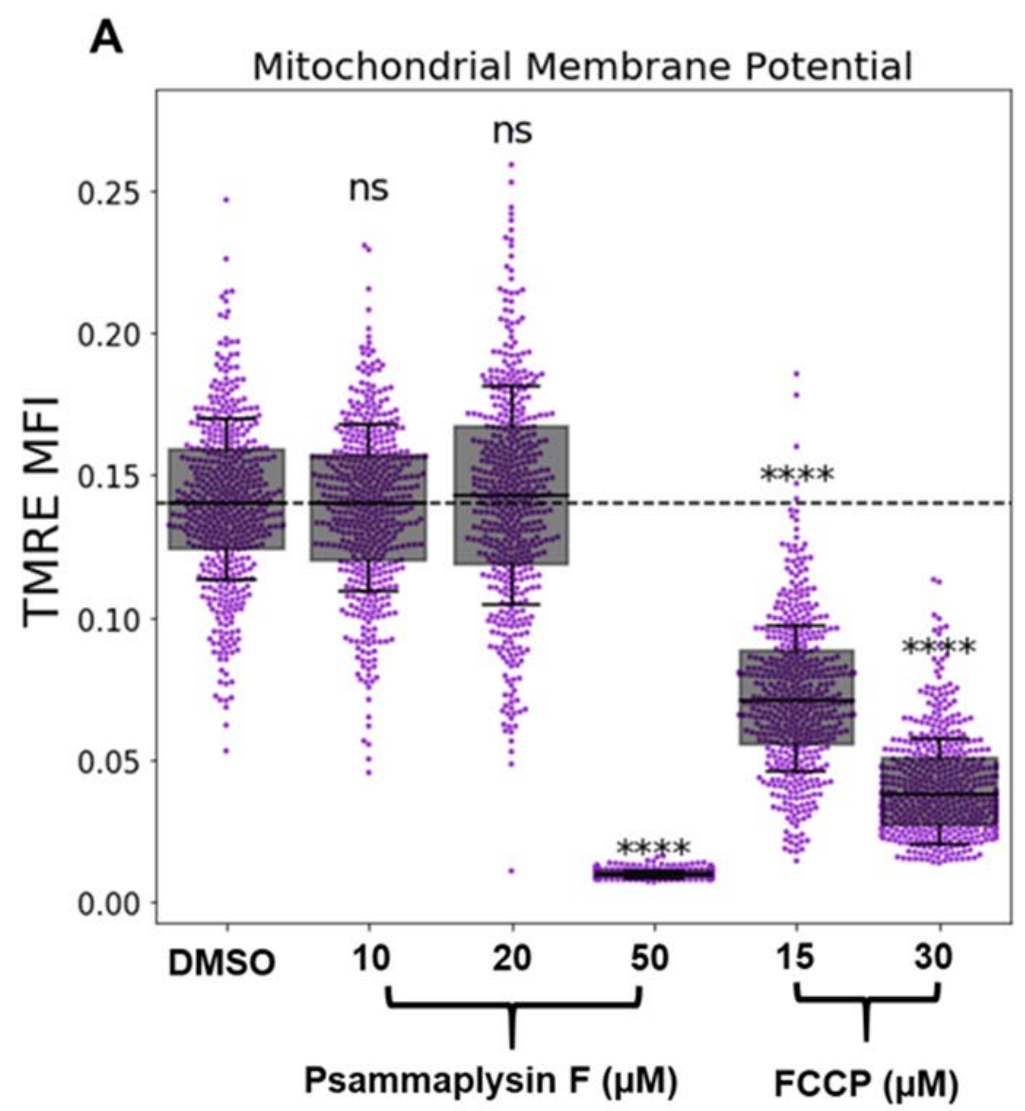

B Mitochondrial Branches

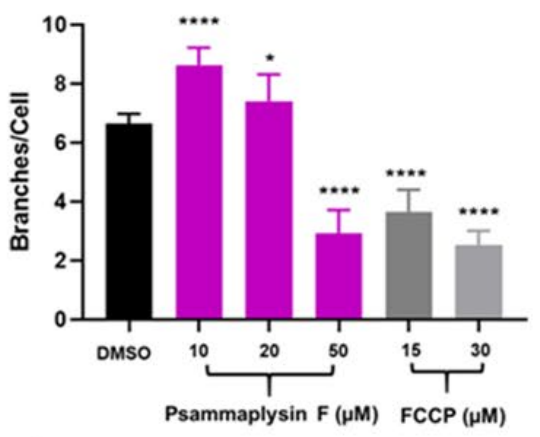

C Mitochondrial End-Points

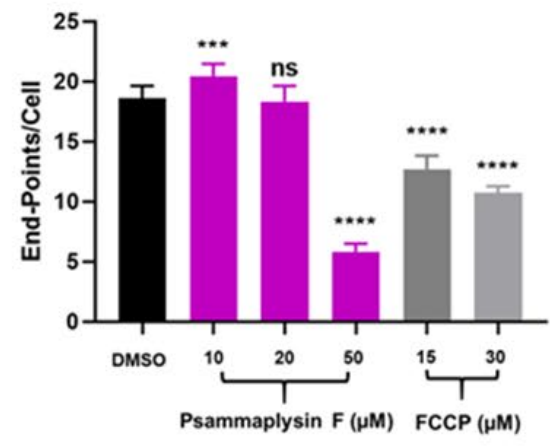

FCCP $(\mu M)$

D
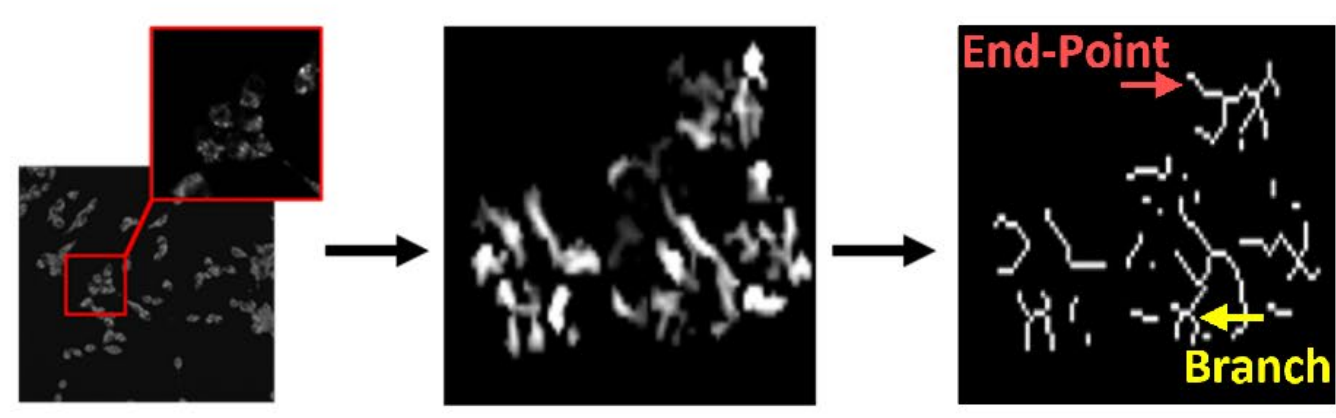

E

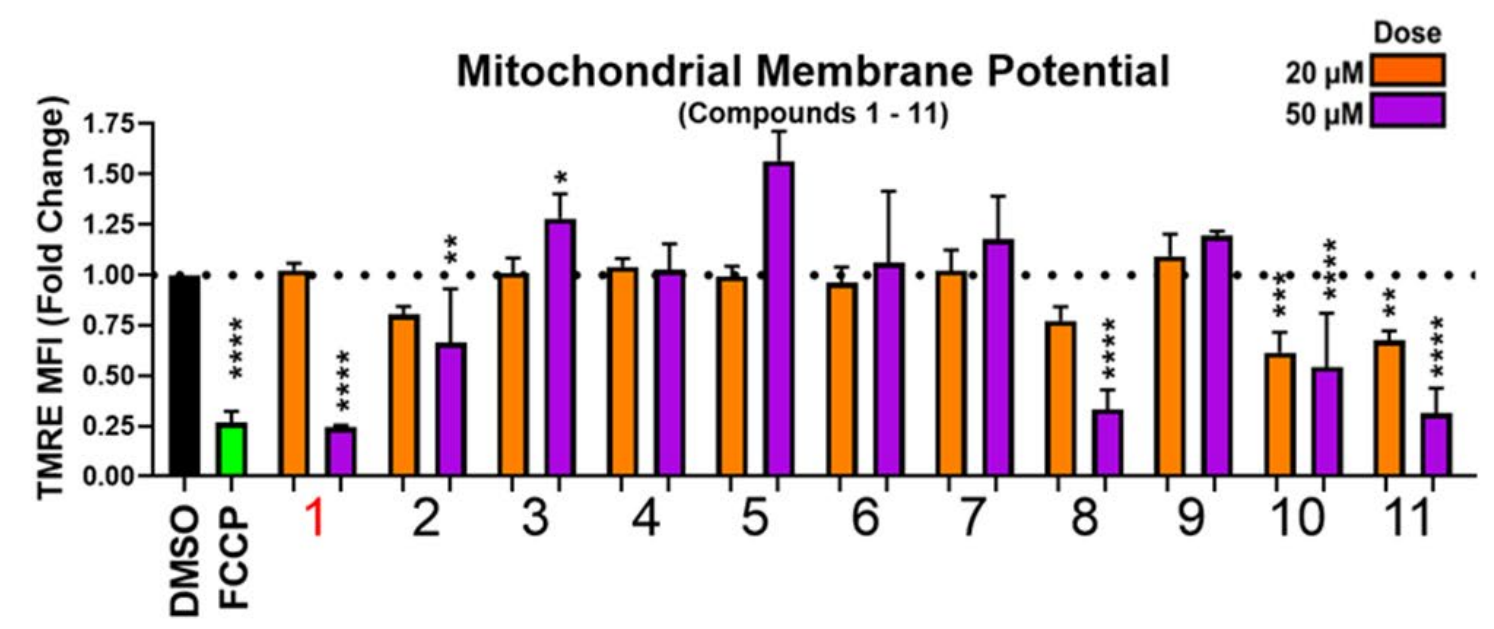


Figure 6: Psammaplysin F (1), urea and amide analogs (2-11) and positive control FCCP dysregulate mitochondrial activity and morphology in LNCaP cells. (A) LNCaP cells were treated with vehicle control (DMSO) or the indicated concentrations of psammaplysin F (1) for $24 \mathrm{~h}$ and processed by mqSCI to measure mitochondrial membrane potential based on mean fluorescent intensity (MFI) of the fluorescent tetramethylrhodamine ethyl ester (TMRE) probe. Morphometric object analysis of (B) mitochondrial branches and (C) mitochondrial end-points was based on MitoTracker Green (MTG) staining. (D) Automated image-analysis workflow of mitochondrial tubularity based on branch and end-point node detection using CellProfiler 3.1.8 (Broad Institute). (E) Mitochondrial membrane potential (process described in A) of LNCaP cells treated with $20 \mu \mathrm{M}$ or $50 \mu \mathrm{M}$ of urea and amide analogs (2-11, 1 included) or FCCP (30 $\mu \mathrm{M})$. Data shown as a fold change of MFI of the fluorescent TMRE probe relative to DMSO control. Statistical analysis for $\mathbf{A}-\mathbf{C}$ and $\mathbf{E}: \mathrm{n}=3$ wells/treatment with $>5000$ cells/well, median $\pm \mathrm{SD}$, each representative of 2 independent experiments. Significance was determined by oneway ANOVA and Dunnett's multiple comparison test; * $\mathrm{p}<0.05, * * \mathrm{p}<0.01, * * * \mathrm{p}<0.001$, $* * * * \mathrm{p}<0.0001, \mathrm{~ns}-$ not significant. 


\section{EXPERIMENTAL SECTION}

General Experimental Procedures. Optical rotations and UV spectra were determined on JASCO P-1020 polarimeter and JASCO V-650 UV/vis spectrophotometer, respectively. ECD spectra were recorded on a JASCO J-715 spectropolarimeter. NMR spectra were recorded in DMSO- $d_{6}$ at $25{ }^{\circ} \mathrm{C}$ on a Bruker Avance HDX $800 \mathrm{MHz}$ spectrometer equipped with a TCI cryoprobe. The ${ }^{1} \mathrm{H}$ and ${ }^{13} \mathrm{C}$ chemical shifts were referenced to the solvent peaks for DMSO- $d_{6}$ at $\delta_{\mathrm{H}} 2.50$ and $\delta_{\mathrm{C}} 39.5$, respectively. LRESIMS were recorded on a Waters ZQ mass spectrometer using a Phenomenex Luna $C_{18}(2) 3 \mu \mathrm{m} 100 \AA(50 \times 4.6 \mathrm{~mm})$ column. HRESIMS data was acquired on a $12 \mathrm{~T}$ Bruker SolariX XR FT-ICR-MS. A Waters 600 pump equipped with a Waters 966 PDA detector and a Gilson 715 liquid handler was used for semi-preparative purification. Alltech $\mathrm{C}_{18}$ bonded silica $(35-75 \mu \mathrm{m}, 150 \AA)$ and a Grace stainless steel guard cartridge $(10 \times 30 \mathrm{~mm})$ were used for pre-adsorption work. A ThermoElectron $\mathrm{C}_{18}$ Betasil $5 \mu \mathrm{m}$ $143 \AA(21.2 \times 150 \mathrm{~mm})$ column was used for semi-preparative HPLC separations while a Phenomenex Luna $\mathrm{C}_{18}$ (2) $5 \mu \mathrm{m} 100 \AA(250 \times 150 \mathrm{~mm})$ column was used to purify the products. All solvents used for chromatography and MS were Lab Scan HPLC grade, and the $\mathrm{H}_{2} \mathrm{O}$ was Millipore Milli-Q PF filtered. All reagents for synthetic work were purchased from SigmaAldrich and used without further purification.

Animal Material. The sponge Hyattella sp. (Spongiidae) was collected by SCUBA diving ( 19 m) at Hervey Bay, Little Woody Island, Sponge Garden, Queensland, Australia during November of 1995, and kept frozen prior to freeze-drying and extraction. A voucher sample (G306299) has previously been lodged at the Queensland Museum, Brisbane.

Extraction and Isolation. The freeze-dried and ground sponge (46 g) was sequentially extracted with $\mathrm{CH}_{2} \mathrm{Cl}_{2}(1.25 \mathrm{~L}, 2 \mathrm{~h})$ and $\mathrm{MeOH}(1.25 \mathrm{~L} \times 2,16 \mathrm{~h})$. Both $\mathrm{CH}_{2} \mathrm{Cl}_{2}$ and $\mathrm{MeOH}$ extracts were combined and dried under reduced pressure to yield a brown gum $(7.5 \mathrm{~g})$. This extract was divided into 15 separate potions ( $\sim 0.5 \mathrm{~g}$ each) then re-suspended in $\mathrm{CH}_{2} \mathrm{Cl}_{2} / \mathrm{MeOH}$, pre-adsorbed to $\mathrm{C}_{18}$ bonded silica and packed into a stainless steel guard cartridge that was subsequently attached to a semi-preparative $\mathrm{C}_{18}$ Betasil HPLC column. Fifteen separate HPLC separations were performed. Isocratic HPLC conditions of $90 \% \mathrm{H}_{2} \mathrm{O}(0.1 \% \mathrm{TFA}) / 10 \% \mathrm{MeOH}$ $(0.1 \%$ TFA) were initially employed for the first $10 \mathrm{~min}$, then a linear gradient to $\mathrm{MeOH}(0.1 \%$ TFA) was run over $40 \mathrm{~min}$, followed by isocratic conditions of $\mathrm{MeOH}(0.1 \% \mathrm{TFA})$ for a further 
$10 \mathrm{~min}$, all at a flow rate of $9 \mathrm{~mL} / \mathrm{min}$ with the ThermoElectron $\mathrm{C}_{18}$ Betasil column. Sixty fractions $(60 \times 1 \mathrm{~min})$ were collected from the start of the HPLC run then analyzed by LRESIMS. Fractions 37-39 contained ion clusters associated with psammaplysin F $(\mathrm{m} / \mathrm{z}$ 744/746/748/750/752. Fractions 37-39 from each of the 15 HPLC separations were combined and solvents evaporated to afford the TFA salt of psammaplysin F (1).

Psammaplysin F TFA Salt (1). Brown stable gum, (290 mg, 0.630\% dry wt); $[\alpha]_{\mathrm{D}}^{25}-63$ (c 0.19, MeOH); ECD (c $\left.3.37 \times 10^{-5} \mathrm{M}, \mathrm{MeOH}\right) \lambda_{\max }(\Delta \varepsilon) 274$ (-1.37), 240 (8.97), $213(-27.8)$ $\mathrm{nm}$; NMR and MS data for compound $\mathbf{1}$ were consistent with literature values. ${ }^{36,38}$

Generation of the Urea Analogs. A solution of psammaplysin F TFA salt (1, $10 \mathrm{mg}$, $0.0135 \mathrm{mmol})$ in dry $\mathrm{CH}_{2} \mathrm{Cl}_{2}(250 \mu \mathrm{L})$ was treated with various isocyanates $(0.135 \mathrm{mmol})$ in anhydrous pyridine $(100 \mu \mathrm{L})$ at room temperature for $16 \mathrm{~h}$ with constant stirring. The reaction crude was dried under $\mathrm{N}_{2}$ and then high vacuum before being pre-adsorbed to $\mathrm{C}_{18}$ bonded silica $(\sim 1 \mathrm{~g})$. This was then packed into a guard cartridge $(10 \times 30 \mathrm{~mm})$ that was subsequently purified on HPLC using a Phenomenex $\mathrm{C}_{18}$ Luna column. Isocratic HPLC conditions of $30 \% \mathrm{H}_{2} \mathrm{O}(0.1 \%$ TFA) $/ 70 \% \mathrm{MeOH}(0.1 \%$ TFA) were employed for the first $10 \mathrm{~min}$; followed by a linear gradient to $\mathrm{MeOH}(0.1 \% \mathrm{TFA})$ over $40 \mathrm{~min}$, and finally isocratic conditions of $\mathrm{MeOH}(0.1 \% \mathrm{TFA})$ for 10 $\mathrm{min}$, all at flow rate of $4 \mathrm{~mL} / \mathrm{min}$. Sixty fractions $(60 \times 1 \mathrm{~min})$ were collected from the start of the HPLC run. The UV active fractions were analyzed by LRESIMS followed by ${ }^{1} \mathrm{H}$ NMR spectroscopy to identify the desired urea products in yields ranging from 8 to $59 \%$.

Compound 2. White amorphous powder, (2.1 mg, 20\%); $[\alpha]_{\mathrm{D}}^{25}-60(c 0.10, \mathrm{MeOH}) ; \mathrm{UV}$ $(\mathrm{MeOH}) \lambda_{\max }(\log \varepsilon) 266(3.86), 214(4.49) \mathrm{nm} ; \mathrm{ECD}\left(c 2.97 \times 10^{-5} \mathrm{M}, \mathrm{MeOH}\right) \lambda_{\max }(\Delta \varepsilon) 287$ (-0.54), 240 (4.87), $214(-25.0) \mathrm{nm} ;{ }^{1} \mathrm{H}$ NMR $\left(800 \mathrm{MHz}, \mathrm{DMSO}-d_{6}\right) \delta_{\mathrm{H}} 0.86(3 \mathrm{H}, \mathrm{t}, J=7.4 \mathrm{~Hz}$, H-26), 1.25 (2H, m, H-25), 1.35 (2H, m, H-24), 2.01 (2H, tt, $J=6.3,6.3 \mathrm{~Hz}, \mathrm{H}-11), 2.68$ (2H, t, $J=7.6 \mathrm{~Hz}, \mathrm{H}-19), 2.74$ (3H, s, H-21), 2.98 (2H, dt, $J=5.5,7.3 \mathrm{~Hz}, \mathrm{H}-23), 3.05$ (1H, d, $J=16.3$ Hz, H-5 $), 3.33(1 \mathrm{H}, \mathrm{d}, J=16.3 \mathrm{~Hz}, \mathrm{H}-5 \alpha), 3.38(2 \mathrm{H}, \mathrm{t}, J=7.6 \mathrm{~Hz}, \mathrm{H}-20), 3.43(2 \mathrm{H}, \mathrm{dt}, J=5.6$, $6.3 \mathrm{~Hz}, \mathrm{H}-10), 3.58$ (3H, s, 3-OMe), 3.95 (2H, t, $J=6.3 \mathrm{~Hz}, \mathrm{H}-12), 4.90$ (1H, d, $J=7.9 \mathrm{~Hz}, \mathrm{H}-$ 7), $6.17(1 \mathrm{H}, \mathrm{t}, J=5.5 \mathrm{~Hz}, 22-\mathrm{NH}), 6.99(1 \mathrm{H}, \mathrm{d}, J=7.9 \mathrm{~Hz}, 7-\mathrm{OH}), 7.28(1 \mathrm{H}, \mathrm{s}, \mathrm{H}-1), 7.52(2 \mathrm{H}$, s, H-15, H-17), $8.74(1 \mathrm{H}, \mathrm{t}, J=5.6 \mathrm{~Hz}, 9-\mathrm{NH}) ;{ }^{13} \mathrm{C}$ NMR (200 MHz, DMSO- $\left.d_{6}\right) \delta_{\mathrm{C}} 13.9(\mathrm{C}-26)$, 19.6 (C-25), 29.4 (C-11), 32.1 (C-24), 32.2 (C-19), 34.0 (C-21), 36.3 (C-10), 37.0 (C-5), 39.8 (C23), 49.0 (C-20), 58.7 (3-OMe), 71.1 (C-12), 79.2 (C-7), 101.5 (C-2), 103.1 (C-4), 117.3 (C-14, 
C-18), 117.5 (C-6), 133.1 (C-15, C-17), 139.1 (C-16), 145.6 (C-1), 147.8 (C-3), 150.7 (C-13), 157.6 (C-22), 157.9 (C-8), 158.1 (C-9); LRESIMS m/z 842 (17), 844 (68), 846 (100), 848 (66), 850 (16) $[\mathrm{M}+\mathrm{H}]^{+}$; HRESIMS $m / z 864.9044[\mathrm{M}+\mathrm{Na}]^{+}$(calcd for $\mathrm{C}_{27} \mathrm{H}_{34}{ }^{79} \mathrm{Br}_{4} \mathrm{~N}_{4} \mathrm{NaO}_{7}$, 864.9053).

Compound 3. White amorphous powder, (7.2 mg, 59\%); $[\alpha]_{\mathrm{D}}^{25}-18(c 0.40, \mathrm{MeOH}) ; \mathrm{UV}$ $(\mathrm{MeOH}) \lambda_{\max }(\log \varepsilon) 265(4.51), 229(4.83) \mathrm{nm} ; \operatorname{ECD}\left(c 2.76 \times 10^{-5} \mathrm{M}, \mathrm{MeOH}\right) \lambda_{\max }(\Delta \varepsilon) 280$ (-0.73), 240 (5.38), $205(-18.1) \mathrm{nm} ;{ }^{1} \mathrm{H}$ NMR (800 MHz, DMSO- $\left.d_{6}\right) \delta_{\mathrm{H}} 2.01(2 \mathrm{H}, \mathrm{tt}, J=6.3,6.3$ Hz H-11), 2.71 (2H, t, $J=7.5$ Hz, H-19), 2.79 (3H, s, H-21), 3.03 (1H, d, $J=16.3 \mathrm{~Hz}, \mathrm{H}-5 \beta)$, $3.32(1 \mathrm{H}, \mathrm{d}, J=16.3 \mathrm{~Hz}, \mathrm{H}-5 \alpha), 3.40$ (2H, t, $J=7.5 \mathrm{~Hz}, \mathrm{H}-20), 3.43(2 \mathrm{H}, \mathrm{m}, \mathrm{H}-10), 3.58(3 \mathrm{H}, \mathrm{s}$, 3-OMe), 3.72 (3H, s, 27-OMe), 3.96 (2H, t, $J=6.3 \mathrm{~Hz}, \mathrm{H}-12), 4.15$ (2H, d, $J=5.8 \mathrm{~Hz}, \mathrm{H}-23)$, $4.91(1 \mathrm{H}, \mathrm{d}, J=7.9 \mathrm{~Hz}, \mathrm{H}-7), 6.78(1 \mathrm{H}, \mathrm{t}, J=5.8 \mathrm{~Hz}, 22-\mathrm{NH}), 6.85(2 \mathrm{H}, \mathrm{d}, J=8.3 \mathrm{~Hz}, \mathrm{H}-26, \mathrm{H}-$ 28), $7.00(1 \mathrm{H}, \mathrm{d}, J=7.9 \mathrm{~Hz}, 7-\mathrm{OH}), 7.13(2 \mathrm{H}, \mathrm{d}, J=8.3 \mathrm{~Hz}, \mathrm{H}-25, \mathrm{H}-29), 7.28$ (1H, s, H-1), $7.54(2 \mathrm{H}, \mathrm{s}, \mathrm{H}-15, \mathrm{H}-17), 8.74(1 \mathrm{H}, \mathrm{t}, J=5.8 \mathrm{~Hz}, 9-\mathrm{NH}) ;{ }^{13} \mathrm{C}$ NMR $\left(200 \mathrm{MHz}, \mathrm{DMSO}-d_{6}\right) \delta_{\mathrm{C}}$ 29.3 (C-11), 32.1 (C-19), 34.1 (C-21), 36.3 (C-5), 36.9 (C-10), 42.9 (C-23), 49.0 (C-20), 55.1 (27-OMe), 58.6 (3-OMe), 71.1 (C-12), 79.1 (C-7), 101.5 (C-2), 103.1 (C-4), 113.5 (C-26, C-28), 117.3 (C-14, C-18), 117.4 (C-6), 128.1 (C-25, C-29), 133.1 (C-15, C-17), 133.2 (C-24), 139.0 (C-16), 145.5 (C-1), 147.7 (C-3), 150.6 (C-13), 157.5 (C-22), 157.9 (C-8, C-27), 158.0 (C-9); LRESIMS m/z 906 (17), 908 (68), 910 (100), 912 (66), 914 (16) [M + H] ; HRESIMS m/z $928.8991[\mathrm{M}+\mathrm{Na}]^{+}$(calcd for $\mathrm{C}_{31} \mathrm{H}_{34}{ }^{79} \mathrm{Br}_{4} \mathrm{~N}_{4} \mathrm{NaO}_{8}, 928.9002$ ).

Compound 4. White amorphous powder, (1.1 mg, 8\%); $[\alpha]_{\mathrm{D}}^{25}-82$ (c 0.10, MeOH); UV (MeOH) $\lambda_{\max }(\log \varepsilon) 290(4.35), 221(4.50) \mathrm{nm}$; ECD $\left(c 2.77 \times 10^{-5} \mathrm{M}, \mathrm{MeOH}\right) \lambda_{\max }(\Delta \varepsilon) 282$ (-1.95), 242 (6.89), $213(-24.5) \mathrm{nm} ;{ }^{1} \mathrm{H}$ NMR (800 MHz, DMSO- $\left.d_{6}\right) \delta_{\mathrm{H}} \delta 1.97(2 \mathrm{H}, \mathrm{tt}, J=6.8$ $6.8 \mathrm{~Hz}, \mathrm{H}-11), 2.49$ (3H, s, H-30), 2.79 (2H, t, $J=7.4 \mathrm{~Hz}, \mathrm{H}-19), 2.96$ (3H, s, H-21), 3.05 (1H, $\mathrm{d}, J=16.3 \mathrm{~Hz}, \mathrm{H}-5 \beta), 3.33(1 \mathrm{H}, \mathrm{d}, J=16.3 \mathrm{~Hz}, \mathrm{H}-5 \beta), 3.41(2 \mathrm{H}, \mathrm{dt}, J=5.8,6.8 \mathrm{~Hz}, \mathrm{H}-10), 3.56$ $(2 \mathrm{H}, \mathrm{t}, J=7.4 \mathrm{~Hz}, \mathrm{H}-20), 3.58$ (3H, s, 3-OMe), 3.86 (2H, t, $J=6.8 \mathrm{~Hz}, \mathrm{H}-12), 4.90$ (1H, d, $J=$ $7.3 \mathrm{~Hz}, \mathrm{H}-7), 6.99$ (1H, d, $J=7.3 \mathrm{~Hz}, 7-\mathrm{OH}), 7.28$ (1H, s, H-1), 7.56 (2H, s, H-15, H-17), 7.57 (2H, d, $J=8.5 \mathrm{~Hz}, \mathrm{H}-24, \mathrm{H}-28), 7.83$ (2H, d, $J=8.5 \mathrm{~Hz}, \mathrm{H}-25, \mathrm{H}-27), 8.57$ (1H, s, 22-NH), 8.73 $(1 \mathrm{H}, \mathrm{t}, J=5.8 \mathrm{~Hz}, 9-\mathrm{NH}) ;{ }^{13} \mathrm{C}$ NMR $\left(200 \mathrm{MHz}, \mathrm{DMSO}-d_{6}\right) \delta_{\mathrm{C}} 26.5(\mathrm{C}-30), 27.1(\mathrm{C}-11), 33.1(\mathrm{C}-$ 19), 34.6 (C-21), 36.7 (C-10), 37.3 (C-5), 49.1 (C-20), 59.5 (3-OMe), 71.4 (C-12), 79.9 (C-7), 
101.9 (C-2), 103.5 (C-4), 117.8 (C-6), 118.3 (C-14, C-18), 119.2 (C-24, C-28), 129.1 (C-25, C27) 130.6 (C-26), 133.2 (C-15, C-17), 139.2 (C-16), 145.5 (C-1), 145.8 (C-23), 148.2 (C-3), 151.1 (C-13), 155.2 (C-22), 158.4 (C-8), 158.5 (C-9), 197.0 (C-29); LRESIMS m/z 904 (17), 906 (68), 908 (100), 910 (66), $912(16)[\mathrm{M}+\mathrm{H}]^{+}$; HRESIMS $m / z 926.8838[\mathrm{M}+\mathrm{Na}]^{+}$(calcd for $\left.\mathrm{C}_{31} \mathrm{H}_{32}{ }^{79} \mathrm{Br}_{4} \mathrm{~N}_{4} \mathrm{NaO}_{8}, 926.8846\right)$.

Compound 5. White amorphous powder, (5.3 mg, 40\%); $[\alpha]_{\mathrm{D}}^{25}-61(c 0.30, \mathrm{MeOH}) ; \mathrm{UV}$ $(\mathrm{MeOH})(\log \varepsilon) 261(4.03), 215(4.50) \mathrm{nm} \mathrm{nm} ; \mathrm{ECD}\left(c 2.93 \times 10^{-5} \mathrm{M}, \mathrm{MeOH}\right) \lambda_{\max }(\Delta \varepsilon) 280$ (-0.75), 241 (5.82), $211(-19.7) \mathrm{nm} ;{ }^{1} \mathrm{H}$ NMR (800 MHz, DMSO- $\left.d_{6}\right) \delta_{\mathrm{H}} 1.33(2 \mathrm{H}, \mathrm{m}, \mathrm{H}-24 \mathrm{~b}, \mathrm{H}-$ 27b), 1.44 (2H, m, H-25b, H-26b), 1.60 (2H, m, H-25a, H-26a), 1.73 (2H, m, H-24a, H-27a), 2.01 (2H, tt, $J=6.8,6.8 \mathrm{~Hz}, \mathrm{H}-11), 2.68$ (2H, t, $J=7.4 \mathrm{~Hz}, \mathrm{H}-19), 2.75(3 \mathrm{H}, \mathrm{s}, \mathrm{H}-21), 3.04(1 \mathrm{H}$, d, $J=16.3 \mathrm{~Hz}, \mathrm{H}-5 \beta), 3.31(1 \mathrm{H}, \mathrm{d}, J=16.3 \mathrm{~Hz}, \mathrm{H}-5 \alpha), 3.38(2 \mathrm{H}, \mathrm{t}, J=7.4 \mathrm{~Hz}, \mathrm{H}-20), 3.42(2 \mathrm{H}$, dt, $J=5.7,6.8 \mathrm{~Hz}, \mathrm{H}-10), 3.58(3 \mathrm{H}, \mathrm{s}, 3-\mathrm{OMe}), 3.84(1 \mathrm{H}, \mathrm{m}, \mathrm{H}-23), 3.96(2 \mathrm{H}, \mathrm{t}, J=6.8 \mathrm{~Hz}, \mathrm{H}-$ 12), $4.90(1 \mathrm{H}, \mathrm{d}, J=7.0 \mathrm{~Hz}, \mathrm{H}-7), 5.84(1 \mathrm{H}, \mathrm{d}, J=7.0 \mathrm{~Hz}, 22-\mathrm{NH}), 7.00(1 \mathrm{H}, \mathrm{d}, J=7.0 \mathrm{~Hz}, 7-$ $\mathrm{OH}), 7.28(1 \mathrm{H}, \mathrm{s}, \mathrm{H}-1), 7.51$ (2H, s, H-15, H-17), $8.74(1 \mathrm{H}, \mathrm{t}, J=5.7 \mathrm{~Hz}, \mathrm{NH}-9) ;{ }^{13} \mathrm{C}$ NMR $(200$ MHz, DMSO- $d_{6}$ ) $\delta_{\mathrm{C}} 23.4$ (C-25, C-26), 29.3 (C-11), 32.0 (C-19), 32.5 (C-24, C-27), 34.0 (C-21), 36.3 (C-10), 36.9 (C-5), 48.8 (C-20), 51.9 (C-23), 58.6 (3-OMe), 71.1 (C-12), 79.1 (C-7), 101.5 (C-2), 103.1 (C-4), 117.2 (C-14, C-18), 117.4 (C-6), 133.1 (C-15, C-17), 139.1 (C-16), 145.5 (C1), 147.7 (C-3), 150.6 (C-13), 157.3 (C-22), 157.9 (C-8), 158.0 (C-9); LRESIMS m/z 854 (17), 856 (68), 858 (100), 860 (66), $862(16)[\mathrm{M}+\mathrm{H}]^{+}$; HRESIMS $m / z 876.9040[\mathrm{M}+\mathrm{Na}]^{+}$(calcd for $\left.\mathrm{C}_{28} \mathrm{H}_{34}{ }^{79} \mathrm{Br}_{4} \mathrm{~N}_{4} \mathrm{NaO}_{7}, 876.9053\right)$.

Compound 6. White amorphous powder, (1.2 mg, 10\%); $[\alpha]_{\mathrm{D}}^{25}-63(c 0.10, \mathrm{MeOH}) ; \mathrm{UV}$ $(\mathrm{MeOH}) \lambda_{\max }(\log \varepsilon) 266(3.91), 214(4.54) \mathrm{nm} ; \mathrm{ECD}\left(c 2.76 \times 10^{-5} \mathrm{M}, \mathrm{MeOH}\right) \lambda_{\max }(\Delta \varepsilon) 289$ (-0.52), 244 (3.48), $204(-15.2) \mathrm{nm} ;{ }^{1} \mathrm{H}$ NMR (800 MHz, DMSO- $\left.d_{6}\right) \delta_{\mathrm{H}} 2.00(2 \mathrm{H}, \mathrm{tt}, J=6.3,6.3$ Hz, H-11), 2.66 (2H, t, $J=7.8, \mathrm{~Hz}, \mathrm{H}-19), 2.68$ (2H, m, H-24), 2.74 (3H, s, H-21), 3.04 (1H, d, $J$ $=16.3 \mathrm{~Hz}, \mathrm{H}-5 \beta), 3.19$ (2H, m, H-23), 3.33 (1H, d, $J=16.3 \mathrm{~Hz}, \mathrm{H}-5 \alpha), 3.34$ (2H, m, H-20), 3.42 $(2 \mathrm{H}, \mathrm{m}, \mathrm{H}-10), 3.58$ (3H, s, 3-OMe), $3.94(3 \mathrm{H}, \mathrm{t}, J=6.3 \mathrm{~Hz}, \mathrm{H}-12), 4.90(1 \mathrm{H}, \mathrm{d}, J=6.5 \mathrm{~Hz}, \mathrm{H}-$ 7), $6.33(1 \mathrm{H}, \mathrm{t}, J=5.5 \mathrm{~Hz}, 22-\mathrm{NH}), 6.99(1 \mathrm{H}, \mathrm{d}, J=6.5 \mathrm{~Hz}, 7-\mathrm{OH}), 7.09$ (2H, m, H-27, H-29), 7.19 (2H, m, H-26, H-30), 7.28 (1H, s, H-1), 7.52 (2H, s, H-15, H-17), 8.73 (1H, t, J = 5.8 Hz, 9$\mathrm{NH}) ;{ }^{13} \mathrm{C}$ NMR (200 MHz, DMSO- $\left.d_{6}\right) \delta_{\mathrm{C}} 29.3$ (C-11), 32.0 (C-19), 34.0 (C-21), 35.2 (C-24), 
36.3 (C-10), 36.9 (C-5), 41.9 (C-23), 48.9 (C-20), 58.6 (3-OMe), 71.1 (C-12), 79.1 (C-7), 101.5 (C-2), 103.1 (C-4), 114.9 (d, $\left.{ }^{2} J_{\mathrm{CF}}=21.7 \mathrm{~Hz}, \mathrm{C}-27, \mathrm{C}-29\right), 117.3$ (C-14, C-18), 117.4 (C-6), 130.3 $\left(\mathrm{d},{ }^{3} J_{\mathrm{CF}}=7.5 \mathrm{~Hz}, \mathrm{C}-26, \mathrm{C}-30\right), 133.1$ (C-15, C-17), 136.0 (C-25), 139.0 (C-16), 145.5 (C-1), 147.7 (C-3), 150.6 (C-13), 157.4 (C-8), 157.9 (C-22), 158.0 (C-9), 160.1 (d, ${ }^{1} J_{\mathrm{CF}}=243.7 \mathrm{~Hz}, \mathrm{C}-$ 28); LRESIMS m/z 908 (17), 910 (68), 912 (100), 914 (66), 916 (16) [M + H] ; HRESIMS m/z $930.8950[\mathrm{M}+\mathrm{Na}]^{+}$(calcd for $\mathrm{C}_{31} \mathrm{H}_{33}{ }^{79} \mathrm{Br}_{4} \mathrm{FN}_{4} \mathrm{NaO}_{7}, 930.8959$ ).

Compound 7. White amorphous powder, (4.9 mg, 44\%); $[\alpha]_{\mathrm{D}}^{25}-59$ (c 0.30, MeOH); UV (MeOH) $\lambda_{\max }(\log \varepsilon) 272$ (3.83), 241 (4.38), 218 (4.16) nm; ECD $\left(c 2.71 \times 10^{-5} \mathrm{M}, \mathrm{MeOH}\right) \lambda_{\max }$ $(\Delta \varepsilon) 280(-0.75), 242(4.45), 211(-14.5) \mathrm{nm} ;{ }^{1} \mathrm{H}$ NMR (800 MHz, DMSO-d $) \delta_{\mathrm{H}} 2.00(2 \mathrm{H}, \mathrm{tt}, J$ $=6.3,6.3 \mathrm{~Hz}, \mathrm{H}-11), 2.80(2 \mathrm{H}, \mathrm{t}, J=7.5 \mathrm{~Hz}, \mathrm{H}-19), 2.94(3 \mathrm{H}, \mathrm{s}, \mathrm{H}-21), 3.05(1 \mathrm{H}, \mathrm{d}, J=16.3$ Hz, H-5 ) $3.31(1 \mathrm{H}, \mathrm{d}, J=16.3 \mathrm{~Hz}, \mathrm{H}-5 \alpha), 3.43(2 \mathrm{H}, \mathrm{dt}, J=5.8,6.3 \mathrm{~Hz}, \mathrm{H}-10), 3.51(2 \mathrm{H}, \mathrm{t}, J=$ $7.5 \mathrm{~Hz}, \mathrm{H}-20), 3.58$ (3H, s, 3-OMe), 3.73 (3H, s, 28-OMe), 3.79 (3H, s, 27-OMe), 3.92 (2H, t, $J$ $=6.3 \mathrm{~Hz}, \mathrm{H}-12), 4.90(1 \mathrm{H}, \mathrm{d}, J=7.7 \mathrm{~Hz}, \mathrm{H}-7), 6.70(1 \mathrm{H}, \mathrm{dd}, J=8.4,1.4 \mathrm{~Hz}, \mathrm{H}-26), 6.94(1 \mathrm{H}$, dd, $J=8.4,8.4 \mathrm{~Hz}, \mathrm{H}-25), 7.02(1 \mathrm{H}, \mathrm{d}, J=7.7 \mathrm{~Hz}, 7-\mathrm{OH}), 7.29(1 \mathrm{H}, \mathrm{s}, \mathrm{H}-1), 7.36(1 \mathrm{H}, \mathrm{dd}, J=$ 8.4, 1.4 Hz, H-24), 7.45 (1H, br s, 22-NH), 7.58 (2H, s, H-15, H-17), 8.77 (1H, t, $J=5.8 \mathrm{~Hz}, 9-$ $\mathrm{NH}) ;{ }^{13} \mathrm{C}$ NMR (200 MHz, DMSO- $d_{6}$ ) $\delta_{\mathrm{C}} 29.3$ (C-11), 32.0 (C-19), 34.3 (C-21), 36.3 (C-10), 36.9 (C-5), 49.5 (C-20), 55.7 (27-OMe), 58.6 (3-OMe), 60.0 (28-OMe), 71.0 (C-12), 79.1 (C-7), 101.5 (C-2), 103.1 (C-4), 107.1 (C-26), 114.0 (C-24), 117.4 (C-6), 117.4 (C-14, C-18), 123.3 (C25), 133.1 (C-15, C-17), 133.4 (C-23), 138.8 (C-16), 138.9 (C-28), 145.6 (C-1), 147.7 (C-3), 150.7 (C-13), 152.1 (C-27), 154.8 (C-22), 157.9 (C-8), 158.0 (C-9); LRESIMS m/z 922 (17), 924 (68), 926 (100), 928 (66), $930(16)[\mathrm{M}+\mathrm{H}]^{+}$; HRESIMS $\mathrm{m} / z 944.8935[\mathrm{M}+\mathrm{Na}]^{+}$(calcd for $\left.\mathrm{C}_{31} \mathrm{H}_{34}{ }^{79} \mathrm{Br}_{4} \mathrm{~N}_{4} \mathrm{NaO}_{9}, 944.8951\right)$.

Compound 8. White amorphous powder, (1.7 mg, 15\%); $[\alpha]_{\mathrm{D}}^{25}-28(c 0.10, \mathrm{MeOH}) ; \mathrm{UV}$ $(\mathrm{MeOH}) \lambda_{\max }(\log \varepsilon) 265$ (3.89), $213(4.45) \mathrm{nm}$; ECD $\left(c 3.03 \times 10^{-5} \mathrm{M}, \mathrm{MeOH}\right) \lambda_{\max }(\Delta \varepsilon) 281$ (-0.40), $241(2.05), 212(-7.68) \mathrm{nm} ;{ }^{1} \mathrm{H}$ NMR (800 MHz, DMSO- $\left.d_{6}\right) \delta_{\mathrm{H}} 2.01(2 \mathrm{H}, \mathrm{tt}, J=6.8,6.8$ Hz, H-11), 2.69 (2H, t, $J=6.0 \mathrm{~Hz}, \mathrm{H}-19), 2.78$ (3H, s, H-21), 3.05 (1H, d, $J=16.3 \mathrm{~Hz}, \mathrm{H}-5 \beta)$, $3.31(1 \mathrm{H}, \mathrm{d}, J=16.3 \mathrm{~Hz}, \mathrm{H}-5 \alpha), 3.37$ (2H, m, H-20), $3.43(2 \mathrm{H}, \mathrm{dt}, J=5.8,6.8 \mathrm{~Hz}, \mathrm{H}-10), 3.58$ (3H, s, 3-OMe), 3.62 (2H, tt, $J=5.7,1.8 \mathrm{~Hz}, \mathrm{H}-23), 3.95(2 \mathrm{H}, \mathrm{t}, J=6.8 \mathrm{~Hz}, \mathrm{H}-12), 4.90(1 \mathrm{H}, \mathrm{d}$, $J=7.8 \mathrm{~Hz}, \mathrm{H}-7), 4.98$ (1H, dq, $J=10.2,1.8 \mathrm{~Hz}, \mathrm{H}-25 \mathrm{~b}), 5.04(1 \mathrm{H}, \mathrm{dq}, J=17.2,1.8 \mathrm{~Hz}, \mathrm{H}-25 \mathrm{a})$, 
$5.78(1 \mathrm{H}, \mathrm{ddt}, J=17.2,10.2,5.7 \mathrm{~Hz}, \mathrm{H}-24), 6.45(1 \mathrm{H}, \mathrm{t}, J=5.7 \mathrm{~Hz}, 22-\mathrm{NH}), 7.01(1 \mathrm{H}, \mathrm{d}, J=$ $7.8 \mathrm{~Hz}, 7-\mathrm{OH}), 7.29$ (1H, s, H-1), $7.55(2 \mathrm{H}, \mathrm{s}, \mathrm{H}-15, \mathrm{H}-17), 8.77$ (1H, t, $J=5.8 \mathrm{~Hz}, 9-\mathrm{NH}) ;{ }^{13} \mathrm{C}$ NMR (200 MHz, DMSO- $d_{6}$ ) $\delta_{\mathrm{C}} 29.3$ (C-11), 32.1 (C-19), 34.0 (C-21), 36.3 (C-5), 36.9 (C-10), 42.5 (C-23), 49.0 (C-20), 58.6 (3-OMe), 71.1 (C-12), 79.1 (C-7), 101.5 (C-2), 103.1 (C-4), 114.1 (C-25), 117.3 (C-14, C-18), 117.4 (C-6), 133.1 (C-15, C-17), 137.1 (C-24), 139.0 (C-16), 145.6 (C-1), 147.7 (C-3), 150.6 (C-13), 157.3 (C-8), 157.9 (C-22), 158.0 (C-9); LRESIMS m/z 826 (17), $828(68), 830(100), 832(66), 834(16)[\mathrm{M}+\mathrm{H}]^{+}$; HRESIMS $m / z 848.8734[\mathrm{M}+\mathrm{Na}]^{+}$ (calcd for $\mathrm{C}_{26} \mathrm{H}_{30}{ }^{79} \mathrm{Br}_{4} \mathrm{~N}_{4} \mathrm{NaO}_{7}, 848.8740$ ).

Compound 9. White amorphous powder, $(3.7 \mathrm{mg}, 30 \%) ; \alpha]_{\mathrm{D}}^{25}-100(c 0.20, \mathrm{MeOH})$; $\mathrm{UV}(\mathrm{MeOH}) \lambda_{\max }(\log \varepsilon) 271$ (3.85), $233(4.61) \mathrm{nm}$; ECD $\left(c 2.55 \times 10^{-5} \mathrm{M}, \mathrm{MeOH}\right) \lambda_{\max }(\Delta \varepsilon)$ 295 (-0.45), 260 (0.34), 243 (-3.59), 237 (-3.87), 215 (-25.6) nm; ${ }^{1} \mathrm{H}$ NMR (800 MHz, DMSO$\left.d_{6}\right) \delta_{\mathrm{H}} ; \delta 1.99(2 \mathrm{H}, \mathrm{tt}, J=6.8,6.8 \mathrm{~Hz}, \mathrm{H}-11), 2.76(2 \mathrm{H}, \mathrm{t}, J=7.4 \mathrm{~Hz}, \mathrm{H}-19), 2.92(3 \mathrm{H}, \mathrm{s}, \mathrm{H}-21)$, $3.14(1 \mathrm{H}, \mathrm{d}, J=16.3 \mathrm{~Hz}, \mathrm{H}-5 \beta), 3.32(3 \mathrm{H}, \mathrm{d}, J=16.3 \mathrm{~Hz}, \mathrm{H}-5 \alpha), 3.40$ (1H, m, H-10b), 3.45 $(1 \mathrm{H}, \mathrm{dt}, J=5.8 .6 .8 \mathrm{~Hz}, \mathrm{H}-10 \mathrm{a}), 3.51$ (2H, t, $J=7.4 \mathrm{~Hz}, \mathrm{H}-20), 3.59$ (3H, s, 3-OMe), 3.89 (2H, t, $J=6.8 \mathrm{~Hz}, \mathrm{H}-12), 6.19(1 \mathrm{H}, \mathrm{s}, \mathrm{H}-7), 6.92(1 \mathrm{H}, \mathrm{dd}, J=7.3,7.3 \mathrm{~Hz}, \mathrm{H}-26), 7.05(1 \mathrm{H}, \mathrm{dd}, J=7.8$, $7.8 \mathrm{~Hz}, \mathrm{H}-33), 7.20$ (2H, dd, $J=7.3,7.3 \mathrm{~Hz}, \mathrm{H}-25, \mathrm{H}-27), 7.31(2 \mathrm{H}, \mathrm{dd}, J=7.8,7.8 \mathrm{~Hz}, \mathrm{H}-32$, H-34), 7.39 (1H, s, H-1), 7.40 (3H, d, $J=7.3 \mathrm{~Hz}, \mathrm{H}-24, \mathrm{H}-28), 7.46$ (2H, d, $J=8.5 \mathrm{~Hz}, \mathrm{H}-31, \mathrm{H}-$ 35), 7.54 (2H, s, H-15, H-17), 8.17 (1H, s, NH-22), 8.95 (1H, t, $J=5.8 \mathrm{~Hz}, \mathrm{NH}-9), 10.18(1 \mathrm{H}, \mathrm{s}$, NH-29); ${ }^{13} \mathrm{C}$ NMR (200 MHz, DMSO- $d_{6}$ ) $\delta_{\mathrm{C}} 29.2$ (C-11), 32.0 (C-19), 34.4 (C-21), 36.4 (C-10), 37.2 (C-5), 49.2 (C-20), 58.7 (3-OMe), 71.0 (C-12), 78.2 (C-7), 102.3 (C-4), 103.0 (C-2), 117.3 (C-14, C-18), 118.0 (C-6), 118.5 (C-31, C-35), 120.0 (C-24, C-28), 121.7 (C-26), 123.3 (C-33), 128.1 (C-25, C-27), 128.9 (C-32, C-34), 133.1 (C-15, C-17), 138.2 (C-30), 138.9 (C-16), 140.5 (C-23), 145.5 (C-1), 148.1 (C-3), 150.6 (C-13), 150.6 (C-29), 154.7 (C-8), 155.2 (C-22), 157.1 (C-9); LRESIMS m/z 981 (17), 983 (68), 985 (100), 987 (66), 989 (16) [M + H] ; HRESIMS m/z $1003.9090[\mathrm{M}+\mathrm{Na}]^{+}$(calcd for $\mathrm{C}_{36} \mathrm{H}_{35}{ }^{79} \mathrm{Br}_{4} \mathrm{~N}_{5} \mathrm{NaO}_{8}, 1003.9111$ ).

Generation of the Amide Analogs. Pivaloyl chloride (5.25 $\mu \mathrm{L}, 0.043 \mathrm{mmol})$ was added dropwise to the mixture of anhydrous pyridine and psammaplysin F TFA salt (1, $10.6 \mathrm{mg}$, $0.0143 \mathrm{mmol}$ ) at $0{ }^{\circ} \mathrm{C}$ with constant stirring for $1 \mathrm{~h}$. The mixture was allowed to warm to $\mathrm{rt}$ and was stirred for further $16 \mathrm{~h}$. The reaction crude was dried under $\mathrm{N}_{2}$ and then high vacuum before 
being pre-adsorbed to $\mathrm{C}_{18}$ bonded silica ( $\left.\sim 1 \mathrm{~g}\right)$. The product(s) were purified by $\mathrm{C}_{18}$ HPLC using the urea purification protocol described above to yield $10\left(0.9 \mathrm{mg}, 6 \%, t_{\mathrm{R}}=27 \mathrm{~min}\right)$ and $11(0.9$ $\left.\mathrm{mg}, 6 \%, t_{\mathrm{R}}=33 \mathrm{~min}\right)$.

Compound 10. White amorphous powder, $(0.9 \mathrm{mg}, 8 \%) ; \alpha]_{\mathrm{D}}^{25}-58(c 0.05, \mathrm{MeOH})$; UV $(\mathrm{MeOH})(\log \varepsilon) 260(4.01), 216(4.57) \mathrm{nm} ; \mathrm{ECD}\left(c 3.03 \times 10^{-5} \mathrm{M}, \mathrm{MeOH}\right) \lambda_{\max }(\Delta \varepsilon) 280(-1.54)$, 241 (11.3), 214 (-34.7) nm; ${ }^{1} \mathrm{H}$ NMR (800 MHz, DMSO-d6) $\delta_{\mathrm{H}} 1.14$ (9H, s, H-24), 2.01 (2H, tt, $J=6.3,6.3 \mathrm{~Hz}, \mathrm{H}-11), 2.74$ (2H, t, $J=7.3 \mathrm{~Hz}, \mathrm{H}-19), 2.96$ (3H, s, H-21), 3.05 (1H, d, $J=16.3$ Hz, H-5 $), 3.31(1 \mathrm{H}, \mathrm{d}, J=16.3 \mathrm{~Hz}, \mathrm{H}-5 \alpha), 3.43$ (2H, dt, $J=5.8,6.3 \mathrm{~Hz}, \mathrm{H}-10), 3.47$ (2H, t, $J=$ $7.3 \mathrm{~Hz}, \mathrm{H}-20), 3.58$ (3H, s, 3-OMe), 3.95 (2H, t, $J=6.3 \mathrm{~Hz}, \mathrm{H}-12), 4.90$ (1H, d, $J=7.8 \mathrm{~Hz}, \mathrm{H}-$ 7), $7.01(1 \mathrm{H}, \mathrm{d}, J=7.8 \mathrm{~Hz}, 7-\mathrm{OH}), 7.29(1 \mathrm{H}, \mathrm{s}, \mathrm{H}-1), 7.50(2 \mathrm{H}, \mathrm{s}, \mathrm{H}-15, \mathrm{H}-17), 8.77$ (1H, t, $J=$ $5.8 \mathrm{~Hz}, 9-\mathrm{NH}) ;{ }^{13} \mathrm{C}$ NMR $\left(200 \mathrm{MHz}, \mathrm{DMSO}-d_{6}\right) \delta_{\mathrm{C}} 27.9$ (C-24), 29.3 (C-11), 31.4 (C-19), 36.1 (C-10), 36.3 (C-21), 36.9 (C-5), 38.2 (C-23), 50.2 (C-20), 58.6 (3-OMe), 71.1 (C-12), 79.1 (C-7), 101.5 (C-2), 103.1 (C-4), 117.3 (C-14, C-18), 117.4 (C-6), 133.1 (C-15, C-17), 138.8 (C-16), 145.6 (C-1), 147.7 (C-3), 150.7 (C-13), 157.9 (C-8), 158.0 (C-9), 175.9 (C-22); LRESIMS m/z 827 (17), 829 (68), 831 (100), 833 (66), 835 (16) [M + H] $]^{+}$; HRESIMS m/z $849.8945[\mathrm{M}+\mathrm{Na}]^{+}$ (calcd for $\mathrm{C}_{27} \mathrm{H}_{33}{ }^{79} \mathrm{Br}_{4} \mathrm{~N}_{3} \mathrm{NaO}_{7}, 849.8944$ ).

Compound 11. White amorphous powder, (0.9 mg, 8\%); $[\alpha]_{\mathrm{D}}^{25}-82(c 0.05, \mathrm{MeOH}) ; \mathrm{UV}$ $(\mathrm{MeOH}) \lambda_{\max }(\log \varepsilon) 260$ (3.87), $211(4.45) \mathrm{nm} ; \operatorname{ECD}\left(c 2.75 \times 10^{-5} \mathrm{M}, \mathrm{MeOH}\right) \lambda_{\max }(\Delta \varepsilon) 294$ (-0.44), 244 (5.66), 214 (-24.2), $208(-22.4) \mathrm{nm} ;{ }^{1} \mathrm{H}$ NMR (800 MHz, DMSO- $\left.d_{6}\right) \delta_{\mathrm{H}} 1.14(9 \mathrm{H}$, s, H-24), 1.17 (9H, s, H-27), 1.98 (2H, tt, $J=6.8,6.8 \mathrm{~Hz}, \mathrm{H}-11), 2.74$ (2H, t, $J=7.3 \mathrm{~Hz}, \mathrm{H}-19)$, $2.96(3 \mathrm{H}, \mathrm{s}, \mathrm{H}-21), 3.04(1 \mathrm{H}, \mathrm{d}, J=16.3 \mathrm{~Hz}, \mathrm{H}-5 \beta), 3.19(1 \mathrm{H}, \mathrm{d}, J=16.3 \mathrm{~Hz}, \mathrm{H}-5 \alpha), 3.43(2 \mathrm{H}$, m, H-10), 3.47 (2H, t, $J=7.3 \mathrm{~Hz}, \mathrm{H}-20), 3.58$ (3H, s, 3-OMe), 3.92 (2H, m, H-12), $6.16(1 \mathrm{H}, \mathrm{s}$ H-7), 7.38 (1H, s, H-1), 7.50 (2H, s, H-15, H-17), 8.95 (1H, t, $J=5.8$ Hz, 9-NH); ${ }^{13} \mathrm{C}$ NMR (200 MHz, DMSO- $\left.d_{6}\right) \delta_{\mathrm{C}} 26.6$ (C-27), 27.9 (C-24), 29.2 (C-11), 31.4 (C-19), 36.1 (C-10), 36.3 (C21), 36.9 (C-5), 38.2 (C-23), 38.5 (C-26), 50.2 (C-20), 58.7 (3-OMe), 71.0 (C-12), 77.6 (C-7), 102.2 (C-4), 104.1 (C-2), 117.2 (C-14, C-18), 118.8 (C-6), 133.1 (C-15, C-17), 138.8 (C-16), 145.8 (C-1), 148.3 (C-3), 150.7 (C-13), 156.9 (C-8), 157.0 (C-9), 174.8 (C-25), 175.9 (C-22); LRESIMS m/z 911 (17), 913 (68), 915 (100), 917 (66), 919 (16) [M + H] ; HRESIMS m/z 933.9515 $[\mathrm{M}+\mathrm{Na}]^{+}$(calcd for $\mathrm{C}_{32} \mathrm{H}_{41}{ }^{79} \mathrm{Br}_{4} \mathrm{~N}_{3} \mathrm{NaO}_{8}, 933.9519$ ). 


\section{Measurement of Cell Cycle Distribution and Mitochondrial Activity by mqSCI.}

LNCaP cells were seeded at 7500 cells/well in poly-L-ornithine coated 96-well plates (IBIDI) with RPMI 1640 (Thermo Fisher) medium supplemented with 5\% FBS (Thermo-Fisher) and incubated a $37{ }^{\circ} \mathrm{C} / 5 \% \mathrm{CO}_{2}$ for $48 \mathrm{~h}$. LNCaP cells were treated with vehicle control (DMSO), ${ }^{54}$ psammaplysin F (1) $(10-50 \mu \mathrm{M})$, synthetic analogs (2-11) $(20$ and $50 \mu \mathrm{M})$ and FCCP $(15-30$ $\mu \mathrm{M}$ ) for $24 \mathrm{~h}$. FCCP is a powerful ionophore uncoupler of oxidative phosphorylation and eliminates mitochondrial membrane potential and TMRE staining. Live cells were then stained with Hoechst 33342 (1 $\mu \mathrm{g} / \mathrm{ml}$, Sigma-Aldrich), TMRE (0.1 $\mu \mathrm{M}$, Sigma Aldrich) and MitoTracker Green $\left(0.2 \mu \mathrm{M}\right.$, ThermoFisher) in serum-free RPMI 1640 for $30 \mathrm{~min}$ at $37{ }^{\circ} \mathrm{C} / 5 \%$ $\mathrm{CO}_{2}$. Images at $10 \mathrm{x}$ and 40x magnifications were automatically acquired with the INCell 2200 Analyzer (GE Healthcare) in the DAPI (ex: $405 \mathrm{~nm})$, FITC (ex: $520 \mathrm{~nm}$ ) and Cy3 channel (ex: $561 \mathrm{~nm})$. Automatic image segmentation and single cell analysis was performed using CellProfiler 3.1.8 (Broad Institute) to measure integrated fluorescence intensity of nuclear DNA and mean fluorescence intensity and branch and end-point numbers of mitochondria with custom image-analysis pipelines. ${ }^{55}$ Cell cycle distribution was calculated using integrated fluorescent intensity extracted from the Hoechst 33342-stained LNCaP nuclei at 10x magnification. Manual gating of nuclei in either the $\mathrm{G}_{0} / \mathrm{G}_{1}$ or $\mathrm{G}_{2} / \mathrm{M}$ phases was performed using the published python based-script, PopulationProfiler ${ }^{53}$ to differentiate $2 \mathrm{n}$ and $4 \mathrm{n}$ DNA content peaks. Nuclear content histograms were then generated using CellProfiler Analyst 2.2.1 (Broad Institute). ${ }^{56}$ Data visualization and statistical analyses generated using the Matplotlib, SciPy, Seaborn, Pandas and NumPy python libraries.

\section{ASSOCIATED CONTENT}

\section{Supporting Information}

The Supporting Information is available free of charge on the ACS Publications website at DOI: 10.1021/acs.jnatprod.

Tabulated NMR data for compounds 1 and 7, 1D/2D NMR spectra for compounds $\mathbf{1}-\mathbf{1 1}$ and HRMS spectra from compounds 2-11. Chemical structures of 6AA, FCCP, and additional figures (PDF) 


\section{AUTHOR INFORMATION}

\section{Corresponding Author}

* Tel.: +61 73735 6043. Fax: +61 73735 6001. E-mail: r.davis@griffith.edu.au.

\section{Notes}

The authors declare no competing financial interest.

\section{ACKNOWLEDGMENTS}

The authors acknowledge the National Health and Medical Research Council (NHMRC) for financial support (Grant APP1024314 to RAD) and thank the Australian Research Council (ARC) for support toward NMR and MS equipment (Grants LE0668477, LE140100119 and LE0237908) and financial support (Grant LP120200339 to RAD). The authors acknowledge the NatureBank biota repository (http://griffith.edu.au/naturebank) from which the marine sponge used for these studies was accessed. We acknowledge W. Loa (Griffith University) for acquiring the HRESIMS measurements. RK would like to thank Griffith University for $\mathrm{PhD}$ scholarships (GUPRS and GUIPRS). This work is supported by the Prostate Cancer Foundation of Australia's Research Program; the Australian Government Department of Health; and the Movember Foundation and Prostate Cancer Foundation of Australia through a Movember Revolutionary Team Award.

\section{References}

(1) Folmer, F.; Jaspars, M.; Dicato, M.; Diederich, M. Biochem. Pharmacol. 2008, $75,603-617$.

(2) Cragg, G. M.; Newman, D. J. Biochim. Biophys. Acta. 2013, 1830, 3670-3695.

(3) Montaser, R.; Luesch, H. Future Med. Chem. 2011, 3, 1475-1489.

(4) Principe, P. P.; Fisher, W. S. J. Nat. Prod. 2018, 81, 2307-2320.

(5) Jiménez, C. ACS Med. Chem. Lett. 2018, 9, 959-961.

(6) Le, V. H.; Inai, M.; Williams, R. M.; Kan, T. Nat. Prod. Rep. 2015, 32, 328-347.

(7) Glaser, K. B.; Mayer, A. M. S. Biochem. Pharmacol. 2009, 78, 440-448.

(8) Yu, M. J.; Zheng, W.; Seletsky, B. M. Nat. Prod. Rep. 2013, 30, 1158-1164. 
(9) Kaul, R.; Risinger, A. L.; Mooberry, S. L. J. Nat. Prod. 2019, 82, 680-685.

(10) Flick, A. C.; Ding, H. X.; Leverett, C. A.; Kyne, R. E.; Liu, K. K. C.; Fink, S. J.; O’Donnell, C. J. J. Med. Chem. 2017, 60, 6480-6515.

(11) Raedler, L. A. Am Health Drug Benefits 2016, 9, 84-87.

(12) Barnes, E. C.; Kumar, R.; Davis, R. A. Nat. Prod. Rep. 2016, 33, 372-381.

(13) Pascolutti, M.; Quinn, R. J. Drug Discov. Today 2014, 19, 215-221.

(14) DeCorte, B. L. J. Med. Chem. 2016, 59, 9295-9304.

(15) Lahlou, M. Pharmacol. Pharm. 2013, 4, 17-31.

(16) Boldi, A. M. Curr. Opin. Chem. Biol. 2004, 8, 281-286.

(17) Barnes, E. C.; Choomuenwai, V.; Andrews, K. T.; Quinn, R. J.; Davis, R. A. Org. Biomol. Chem. 2012, 10, 4015-4023.

(18) Choomuenwai, V.; Andrews, K. T.; Davis, R. A. Bioorg. Med. Chem. 2012, 20, $7167-7174$.

(19) Kumar, R.; Sadowski, M. C.; Levrier, C.; Nelson, C. C.; Jones, A. J.; Holleran, J. P.; Avery, V. M.; Healy, P. C.; Davis, R. A. J. Nat. Prod. 2015, 78, 914-918.

(20) Kumar, R.; Duffy, S.; Avery, V. M.; Davis, R. A. Bioorg. Med. Chem. Lett. 2017, 27, 4091-4095.

(21) Carroll, A. R.; Copp, B. R.; Davis, R. A.; Keyzers, R. A.; Prinsep, M. R. Nat. Prod. Rep. 2019, 36, 122-173.

(22) MarinLit http://pubs.rsc.org/marinlit/ (accessed 30 January 2020)

(23) Carroll, A. R.; Copp, B. R.; Davis, R. A.; Keyzers, R. A.; Prinsep, M. R. Nat. Prod. Rep. 2020, 139-294, 139-294.

(24) Blunt, J. W.; Carroll, A. R.; Copp, B. R.; Davis, R. A.; Keyzers, R. A.; Prinsep, M. R. Nat. Prod. Rep. 2018, 35, 8-53.

(25) Göthel, Q.; Sirirak, T.; Köck, M. Beilstein J. Org. Chem 2015, 11, 2334-2342.

(26) El-Demerdash, A.; Moriou, C.; Toullec, J.; Besson, M.; Soulet, S.; Schmitt, N.; Petek, S.; Lecchini, D.; Debitus, C.; Al-Mourabit, A. Mar. Drugs 2018, 16, 146.

(27) Moosa, B. A.; Sagar, S.; Li, S.; Esau, L.; Kaur, M.; Khashab, N. M. Bioorg. Med. Chem. Lett. 2016, 26, 1629-1632.

(28) Peng, J.; Li, J.; Hamann, M. T. Alkaloids Chem. Biol. 2005, 61, 59-262. 
(29) Mudianta, I. W.; Skinner-Adams, T.; Andrews, K. T.; Davis, R. A.; Hadi, T. A.; Hayes, P. Y.; Garson, M. J. J. Nat. Prod. 2012, 75, 2132-2143.

(30) Mándi, A.; Mudianta, I. W.; Kurtán, T.; Garson, M. J. J. Nat. Prod. 2015, 78, 2051-2056.

(31) Lee, Y.-J.; Han, S.; Lee, H.-S.; Kang, J. S.; Yun, J.; Sim, C. J.; Shin, H. J.; Lee, J. S. J. Nat. Prod. 2013, 76, 1731-1736.

(32) Shaala, L.; Youssef, D.; Badr, J.; Sulaiman, M.; Khedr, A. Mar. Drugs 2015, 13, $1621-1631$.

(33) Sirimangkalakitti, N.; Yokoya, M.; Chamni, S.; Chanvorachote, P.; Plubrukrn, A.; Saito, N.; Suwanborirux, K. Chem. Pharm. Bull. 2016, 64, 258-262.

(34) Rotem, M.; Carmely, S.; Kashman, Y.; Loya, Y. Tetrahedron 1983, 39, 667-676.

(35) Tsukamoto, S.; Kato, H.; Hirota, H.; Fusetani, N. Tetrahedron 1996, 52, 8181-8186.

(36) Yang, X.; Davis, R. A.; Buchanan, M. S.; Duffy, S.; Avery, V. M.; Camp, D.; Quinn, R. J. J. Nat. Prod. 2010, 73, 985-987.

(37) Ichiba, T.; Scheuer, P. J.; Kelly-Borges, M. J. Org. Chem. 1993, 58, 4149-4150.

(38) Liu, S.; Fu, X.; Schmitz, F. J.; Kelly-Borges, M. J. Nat. Prod. 1997, 60, 614-615.

(39) Christen, K. E.; Davis, R. A.; Kennedy, D. Int. J. Biochem. Cell Biol. 2019, 112, 24-38.

(40) Zulfiqar, B.; Jones, A. J.; Sykes, M. L.; Shelper, T. B.; Davis, R. A.; Avery, V. M. Molecules 2017, 22, 1715.

(41) Kurimoto, S.-i.; Ohno, T.; Hokari, R.; Ishiyama, A.; Iwatsuki, M.; Ōmura, S.; Kobayashi, J. i.; Kubota, T. Mar. Drugs 2018, 16, 463.

(42) NatureBank, Griffith Institute for Drug Discovery http://griffith.edu.au/naturebank (accessed 15 January 2020)

(43) Ghosh, A. K.; Brindisi, M. J. Med. Chem. 2019, 10.1021/acs.jmedchem.1029b01541.

(44) Byrd, A. K.; Zybailov, B. L.; Maddukuri, L.; Gao, J.; Marecki, J. C.; Jaiswal, M.; Bell, M. R.; Griffin, W. C.; Reed, M. R.; Chib, S.; Mackintosh, S. G.; MacNicol, A. M.; Baldini, G.; Eoff, R. L.; Raney, K. D. J. Biol. Chem. 2016, 291, 18041-18057.

(45) Levrier, C.; Sadowski, M. C.; Nelson, C. C.; Davis, R. A. J. Nat. Prod. 2015, 78, 2908-2916. 
(46) Salerni, B. L.; Bates, D. J.; Albershardt, T. C.; Lowrey, C. H.; Eastman, A. Mol. Cancer Ther. 2010, 9, 791-802.

(47) Levrier, C.; Sadowski, M. C.; Rockstroh, A.; Gabrielli, B.; Kavallaris, M.; Lehman, M.; Davis, R. A.; Nelson, C. C. Mol. Cancer Ther. 2017, 16, 3-15.

(48) Pendergrass, W.; Wolf, N.; Poot, M. Cytom. Part A 2004, 61, 162-169.

(49) Antico Arciuch, V. G.; Elguero, M. E.; Poderoso, J. J.; Carreras, M. C. Antioxid. Redox Signaling 2012, 16, 1150-1180.

(50) Hirusaki, K.; Yokoyama, K.; Cho, K.; Ohta, Y. Sci. Rep. 2017, 7, 1-8.

(51) Shoichet, B. K. J. Med. Chem. 2006, 49, 7274-7277.

(52) Wai, T.; Langer, T. Trends Endocrinol. Metab. 2016, 27, 105-117.

(53) Matuszewski, D. J.; Wählby, C.; Puigvert, J. C.; Sintorn, I.-M. PLoS One 2016, 11, e0151554.

(54) Sadowski, M. C.; Pouwer, R. H.; Gunter, J. H.; Lubik, A. A.; Quinn, R. J.; Nelson, C. C. Oncotarget 2014, 5, 9362-9381.

(55) McQuin, C.; Goodman, A.; Chernyshev, V.; Kamentsky, L.; Cimini, B. A.; Karhohs, K. W.; Doan, M.; Ding, L.; Rafelski, S. M.; Thirstrup, D.; Wiegraebe, W.; Singh, S.; Becker, T.; Caicedo, J. C.; Carpenter, A. E. PLoS Biol. 2018, 16, e2005970.

(56) Jones, T. R.; Kang, I. H.; Wheeler, D. B.; Lindquist, R. A.; Papallo, A.; Sabatini, D. M.; Golland, P.; Carpenter, A. E. BMC Bioinf. 2008, 9, 482. 
TOC/Abstract Graphic
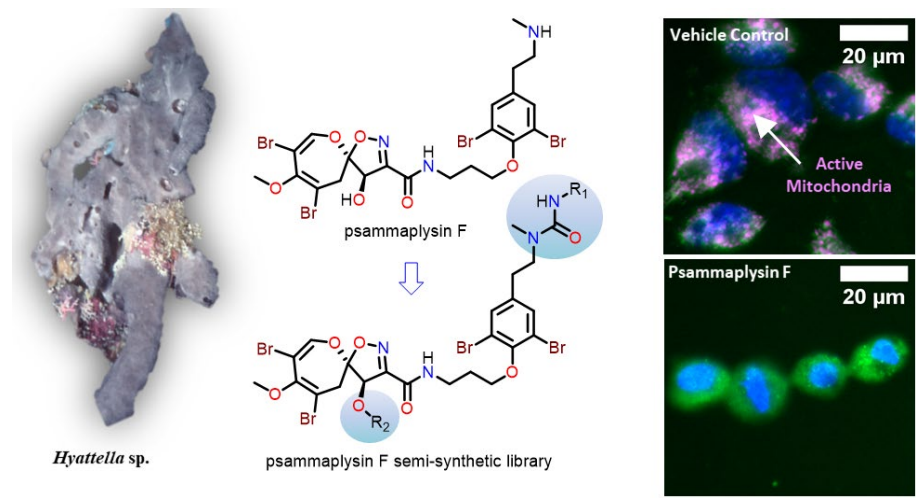